\title{
DOES RELIGION SUPPRESS GENDER DIFFERENCES IN VALUES? A Cross-National Examination
}

\author{
Landon Schnabel ${ }^{1}$ \\ Indiana University, Bloomington
}

\begin{abstract}
Women are typically more liberal than men. But on some issues related to "traditional moral values"-including sexuality and the beginning and end of life - women are just as if not more conservative than men. This study examines the role of religion in complicating the relationship between gender and values cross-nationally, with particular attention to variation across religious groups and contexts. Using data from a diverse set of 56 countries in the World Values Survey $(\mathrm{N}=85,181)$, I find that religiousness suppresses what would otherwise be larger and more consistent gender differences in values among Christians. Among most other groups, including Jews, Hindus, Buddhists, Taoists, and Muslims in non-Muslim contexts, religiousness does not greatly alter gender differences in values. However, among Muslims in Muslim-majority contexts - where men tend to be more religious than women — religiousness amplifies what would otherwise be smaller gender differences in values. Accordingly, gender differences in values tend to be larger among Muslims than Christians. I conclude that religions are complex and powerful social structures with heterogeneous social consequences.
\end{abstract}

Keywords: Gender; Religion; Values; Morality; Attitudes

Last Revised: 4/13/2018

Running Head: Gender Differences in Values

Word Count: 10,868

Figures: 2

Tables: 7

THIS IS A DRAFT. DO NOT QUOTE OR CIRCULATE WITHOUT AUTHOR PERMISSION.

\footnotetext{
${ }^{1}$ I am grateful to Brian Powell for exceptional feedback on this project. I would also like to thank participants in the Indiana University Politics, Economy, and Culture Workshop for helpful comments. Direct correspondence to Landon Schnabel, Department of Sociology, Indiana University, 744 Ballantine Hall, 1020 E. Kirkwood Ave., Bloomington, IN 47405. Email: lpschnab@indiana.edu.
} 
Women tend to be more liberal than men. In many contexts, women are more likely to claim liberal identities, espouse egalitarian values, and vote for progressive politicians (Beutel and Marini 1995; Box-Steffensmeier, DeBoef, and Lin 2004; Charrad 2011; Davis and Robinson 1991; Hadler 2012; Inglehart and Norris 1999; Manza and Brooks 1998; McDermott 2016; Pratto, Stallworth, and Sidanius 1997; Shapiro and Mahajan 1986). Yet, in a gender-and-politics paradox, women are just as if not more conservative than men on certain issues related to notions of "traditional morality" - including gender-related issues such as abortion —in at least some contexts (Barkan 2014; Schnabel 2018). In another gender paradox, religion tends to be mendominated and yet women-populated (Edgell, Frost, and Stewart 2017). Historic religious figures and current religious leaders are predominantly men, and religion often promotes patriarchal beliefs and gender inequality (Edgell 2006; Edgell and Docka 2007; Schnabel 2016a). Nevertheless, women being more religious than men is one of the most consistent findings in the social sciences (Hoffmann 2009). Although the gender gap in religion is frequently noted, its political repercussions are largely ignored (but see Rinehart and Perkins 1989). As I will demonstrate, gender differences in religion help explain the gender-and-politics paradox on certain "traditional moral values"2 related to sexuality and the beginning and end of life. In this study, I argue that religion intersects with social status characteristics such as gender and that the social consequences of religiosity vary across religious groups and contexts (Read and Eagle 2014; Schnabel 2016b; Stewart, Frost, and Edgell 2017; Wilde and Glassman 2016). For example, the experiences and perspectives of Muslim women and men could be

\footnotetext{
2 The "traditional" adjective and scare quotes indicate that these are based on particular, typically conservative, notions of what is moral. As Inglehart and Welzel (2005) have noted, the word "traditional" can mean many things due to varied traditions and values over the course of human history, but here I follow the usage of "traditional" by Inglehart, Welzel, and others to refer to a set of purity prohibitions typically juxtaposed with progressive rational values. I will at times use moral values or values without scare quotes as shorthand for "traditional moral values."
} 
expected to differ from Christian women and men, and we might expect different social consequences to religiosity across these groups. Most social scientific research focuses on the United States and other Western countries, and we should consider whether established patterns found in the West are universal social phenomena or specific to certain cultural contexts (Adamczyk 2017; Norris and Inglehart 2011). In the study of religion specifically, most of what we know is based on surveys of Christians in the U.S. and Europe (Smilde and May 2015). Islam, the world's second largest religion, is the most disproportionately understudied, and a few studies have suggested the supposedly "universal" phenomenon of women being more religious than men varies across religious groups with different patterns among Muslims than among Christians (Hackett, Murphy, and McClendon 2016; Schnabel 2015; Schnabel, Hackett, and McClendon 2017; Sullins 2006).

W.E.B. Du Bois, Angela Davis, Karl Marx, Georg Simmel, and others have said religion provides psychological support to the disadvantaged and thereby suppresses their political consciousness (Du Bois 1903; Davis 1971; Marx 1970; Simmel 1950). Religion may, therefore, help explain the gender-and-politics paradox of women sometimes holding more conservative values than men on issues like abortion. But the theorists listed above spoke about religion in Christian contexts, and different religious systems may have led to different conclusions. Christianity specifically may be a feminine-typed "underdog" religion, appealing more to women based on gendered social norms and women's structurally-disadvantaged social status (Norris and Inglehart 2008; Schnabel 2016b). Subsequently, we may find patterns consistent with theoretical arguments about religion being an "opiate" in Christian contexts, with religion helping to explain the gender-and-politics paradox. But just because women may find more psychological or other benefits and thus be more religious in Christianity — which emphasizes 
stereotypically feminine-typed traits such as sympathy, forgiveness, and communalism, saying that the oppressed will inherit the earth and to turn the other cheek in response to oppressionthat does not mean the same will be true in other religious systems. Therefore, although religion may suppress gender differences in values among Christians, it may not do so among other groups where religion is not disproportionately appealing to women.

To examine whether and how religion complicates the relationship between gender and values, whether this can help explain the gender-and-politics paradox, and the extent to which different religions have different social implications, I use World Values Survey data to examine the interrelationship between gender, religion, and values with special attention to variation across religious groups and contexts. Context can mean many different things, and here I focus on country context with particular attention to variation between where people are religious minorities vs. majorities. I find that religion helps explain the gender-and-politics paradox, suppressing gender gaps in traditional moral values and general political partisanship. But I also find that while this pattern is pronounced among Christians across contexts, the opposite pattern is true among Muslims in Muslim-majority contexts where religiousness amplifies gender differences in values and partisanship.

\section{THEORETICAL BACKGROUND}

Women are often, but not always, more liberal than men Women tend to be more liberal than men across many measures and contexts (Beutel and Marini 1995; Eagly et al. 2004; Hadler 2012; Inglehart and Norris 1999; Shapiro and Mahajan 1986). According to the underdog principle and related theories, women face disadvantage, feel concern for similarly marginalized groups, develop a greater awareness of oppression and structural inequality, and adopt a general set of liberal values (Davis and Robinson 1991; Schuman and 
Harding 1963). Their greater awareness of systemic —as opposed to individual—reasons for inequality subsequently makes women and other disadvantaged groups less likely to believe in legitimating ideologies of racism, sexism, nationalism, etc. that justify social hierarchies and inequalities (Sidanius, Pratto, and Bobo 1994), more likely to recognize and distrust oppressive norms, policies, and institutions (Collins 2000), and, therefore, more likely to develop liberal partisanship and hold liberal positions across a broad range of social, political, and economic issues (Davenport 2016).

Other theories about positionality, power, and politics across the social sciences make arguments similar to the underdog principle. For example, social dominance theory in psychology suggests that structurally-disadvantaged groups, including women, have lower preference for social dominance and hierarchy, and that lower levels of social dominance promote more tolerant and accepting attitudes (Eagly et al. 2004; Sidanius and Pratto 1999; Sidanius et al. 1994). Other work has made similar arguments about marginalized minority groups, a shared sense of group position, support for diversity and pluralism, and the development of a general set of liberal values without invoking the underdog principle or social dominance theory by name (Davenport 2016; Hoffman 2000; Hughes and Tuch 2003).

In short, the "underdog" principle and related positionality theories suggest that women, along with other disadvantaged groups, develop more liberal values and partisanship due to a greater awareness of structural inequality, solidarity with other disadvantaged groups, and lower preference for social dominance (Davis and Robinson 1991, 2006; Eagly et al. 2004; Hunt 1996; Pratto et al. 1997; Robinson and Bell 1978; Schuman and Harding 1963). Other work suggests that feminine-typed psychological characteristics such as communalism and concern for others are linked to more progressive politics (McDermott 2016), and that conservative politics are 
gender-typed as more aggressive and dominant (Messner 2013; Winter 2010). Consistent with the underdog principle and research on the link between femininity and liberalness, research on the U.S. has found women more politically tolerant (Box-Steffensmeier et al. 2004; Herek 2002; Olson, Cadge, and Harrison 2006), more likely to express concern for the well-being of others (Beutel and Marini 1995; Conover 1988), and more likely to support policies that promote the welfare of vulnerable populations (Blekesaune and Quadagno 2003).

\section{The Underdog Paradox}

Positionality and status theories such as the underdog principle predict that structurallydisadvantaged groups will be consistently more liberal (Davenport 2016; Robinson and Bell 1978; Schuman and Harding 1963). Although women are frequently more liberal than men, women and men hold similar attitudes on some issues. And, in what I call an underdog paradox, there are even issues where we might expect women to be more liberal but they can actually be significantly more conservative (e.g., abortion) (Barkan 2014). In fact, a recent study found that women tend to be no more liberal or even significantly more conservative than men on many specific social issues, especially those issues - like sexuality, abortion, and suicide-linked to religious norms and prohibitions (Schnabel 2018). Why are women and other disadvantaged groups not as liberal as we might expect on the basis of status-based theories of political values? Religion is one possible explanation. Religion is an important part of many people's lives, shaping how they interpret reality, define themselves, and develop social and political values. And past research has suggested women are more religious than men.

Women are often, but not always, more religious than men

Structurally-disadvantaged groups sometimes hold values that may seem to limit their rights and well-being. In another paradox — which I will argue is related to and can help explain the 
underdog paradox - religion is men-dominated and yet women-populated. Although religion can promote patriarchal beliefs and gender inequality (Edgell 2006; Edgell and Docka 2007; Schnabel 2016a), women being more religious than men is one of the most consistent findings in the social sciences and has motivated a vibrant literature on how women exert agency in conservative and even patriarchal religions (Agadjanian 2015; Avishai 2008; Burke 2012; Charrad 2011; Khurshid 2015; Prickett 2015; Rao 2015).

Various theories have been used to explain gender differences in religiosity, including some that argue for universal sex differences as opposed to context-specific gender differences (Beit-Hallahmi 2014; Miller and Stark 2002; Stark 2002). The literature is not yet settled, but explanations that emphasize social structure, status, and gendered norms and expectations seem promising (Edgell et al. 2017; Francis and Wilcox 1998; Hastings and Lindsay 2013; Norris and Inglehart 2008; Schnabel 2016b; de Vaus and McAllister 1987) and are consistent with recent findings about how gender differences may vary across religious groups (Hackett et al. 2016; Schnabel 2015; Schnabel et al. 2018). In fact, gender differences in religion may be a function of the same types of social processes - such as structural disadvantage, gender socialization, and gender-typing of social institutions - that produce gender differences in politics.

If, as several foundational social theorists have argued, religion provides comfort to disadvantaged groups and suppresses their liberal politics, gender differences in religiousness may help explain the underdog paradox. Karl Marx (1970 [1843]), for example, called religion the opium of the people, suggesting that religion is a key agent of false consciousness that helps compensate for hardship and thereby distracts people from the root causes of inequality and the disadvantages they face within an unfair system. Others such as W. E. B. Du Bois, Georg Simmel, and Max Weber made similar — though distinct — arguments about religion, saying 
religion can make social relations seem like part of a social order set in place by a just and fair higher power, thus legitimating the position of those in power and making those without power more likely to accept their lot in life. More recently, feminist Marxists such as Angela Davis (1971) have applied Marx's ideas about religion to better understand inequality, religion, and politics.

Marx and some others argued religion is primarily a distraction, but religion is a complex and powerful social structure that does not necessarily make people less political—instead, it could change their politics, promoting traditional values and conservative partisanship. Religion and conservative politics are closely linked (Norris and Inglehart 2011) and research in the social psychological study of religion suggests that religion promotes system-justifying beliefs that enforce exclusionary moral boundaries, highlight individual responsibility over systemic causes of inequality, and reinforce the status quo (Edgell 2012; Jost et al. 2014; Longest, Hitlin, and Vaisey 2013; Rankin, Jost, and Wakslak 2009). In other words, religious schemas tend to be oriented toward traditional moral values and conservative partisanship. Much research has focused on the close link between religion and U.S. politics (Hout and Fischer 2014; Putnam and Campbell 2010), and cross-national research has similarly found a link between religion and conservative politics (Norris and Inglehart 2011). If women are disproportionately drawn to religion, its values-shaping power could disproportionately shape their moral dispositions and thereby suppress what might otherwise be comparatively greater liberalism among women in relation to men.

Social theorists have suggested religion may help explain what Marx called false consciousness — and thereby potentially account for what I call the underdog paradox — but this theorizing should be put to the test empirically. A few studies have suggested that religion may 
help explain surprising patterns in the attitudes of women and racial minorities, but typically considered only one issue at a time and focused on the United States (Adamczyk, Boyd, and Hayes 2016; Barkan 2014; Cassese and Holman 2016, 2017; Sherkat, de Vries, and Creek 2010; Wilcox 1992). The potential impact of religion on group differences in political values theorized by Marx, Du Bois, Davis and others should be further examined across more issues and contexts. Importantly, these theorists frequently spoke from experience living in Christian-majority contexts, and Christianity has been labeled by some as a feminine-typed underdog religion that is particularly appealing to the downtrodden and oppressed (Junge and Storkel 2014; Schnabel 2017). Other religions, and Islam in particular, have been highlighted as potentially more masculine-typed (Samuel 2011). Accordingly, a few recent studies suggest that gender differences in religiousness may vary across different religious groups, with women being more religious than men a phenomenon pronounced among Christians, smaller among some groups, and perhaps even reversed among others (Hackett et al. 2016; Schnabel 2015; Schnabel et al. 2018; Sullins 2006). If gender differences in religiousness vary across groups, and if these gender differences in religiousness influence values, then religion may have different impacts on gender gaps in values across religious groups.

\section{Moving Beyond the Christian West}

One of the most important potential advances in the social sciences generally (Stevens, MillerIdriss, and Shami 2018), and the social scientific study of religion specifically (Smith et al. 2013), is to move beyond the Christian West. Social scientific research on religion focuses overwhelmingly on the United States and Christians: Using data from 40 years of articles on religion in generalist and specialist journals, Smilde and May (2015) confirmed that "research on the United States, Christianity, and most specifically Protestantism still dominate sociology 
journal publications on religion" (p. 369; also see Cadge, Levitt, and Smilde 2011; Kniss 2014; Smith et al. 2013). In fact, they found no change over time in how many studies focus on the U.S. alone, and even a slight rise in the proportion of articles focused on Protestantism. Articles not focused on the U.S. tend to focus on Europe, and only $3 \%$ of articles include the Middle East. Despite Islam being the world's second largest religion — its adherents make up about a quarter of the world's population — new religious movements are covered more than twice as frequently as Islam (9\% versus $4 \%$ of articles).

Social scientific understandings of religion are frequently limited by a narrow focus on regions where religion may be less important than in the past. In fact, this narrow focus has produced problematic answers to basic questions such as trends in religiosity over time. The European path toward secularization was long assumed to be the trajectory that the entire world would follow, but recent global research indicates that this secularization trajectory may not be transferable to other parts of the world (Hackett et al. 2015). All religions and religious cultures are not the same, and the social experiences of different groups of people such as women and men can vary across contexts. Whereas much past research asserted women are universally more religious than men, more recent research suggests that gender differences in religiousness may vary across groups and contexts (Hackett et al. 2016; Schnabel et al. 2018). And if gender differences in religiousness vary across groups, the impact of religiousness on gender differences in values could be expected to vary as well. If, for example, Christian women are substantially more religious than Christian men, then women's greater religiousness may suppress what would otherwise be larger gender differences in values. If there are smaller or reverse gender differences among Muslims, however, then religiousness may suppress gender differences in values among Christians but not Muslims. 
Beyond gender differences in religiousness varying across groups, the impact of religiousness on moral values may vary across groups with different beliefs and norms (Adamczyk and Pitt 2009; Finke and Adamczyk 2008; Kucinskas 2010). For example, although monotheistic religions may have consistently conservatizing influences on what people think about sexuality (Adamczyk and Hayes 2012; Bartkowski and Read 2003), different views on the idea of a soul and afterlife among Jews than among Christians and Muslims could produce different patterns on views toward suicide. Moreover, religious systems not as closely tied to traditional sexual mores, such as Buddhism and Taoism, may not conservatize adherents' values. The social consequences of religion, therefore, may (1) intersect with social status characteristics including gender and (2) vary across different religious groups and contexts.

\section{Expectations}

Women tend to be more liberal than men, but on certain issues_-including sexuality and the beginning and end of life-women can be just as if not more conservative than men. I have proposed that religion may be complicating what might otherwise be more consistent and expected gender differences in values. If women are more religious than men, and religiousness is linked to conservative values, then religion could suppress what would otherwise be larger and more consistent gender differences in values. But gender differences in religiousness - and the relationship between religiosity and values - may vary across religious groups. For example, as recent research has begun to suggest, women may be more religious among Christians but not Muslims due to the gender-typing of religions, religious norms and expectations, and/or different types of compensatory incentives provided by religion (this study considers whether gender differences in religiousness vary across groups, but not why). But not all Christians or Muslims are the same, and we should expect variation, for example, between Christians in the West versus 
the East or between Muslims where they are a minority group versus where they are the majority.

Expectation 1: Gender differences in religiousness vary across religious groups and contexts.

Research consistently demonstrates that more religious people typically have more conservative moral values, especially on issues related to sexuality and suicide (which are in turn related to overarching value systems emphasizing the "sanctity" of procreation and the beginning and end of life). But the impact of religiousness could vary across religious groups, with stronger impacts of religiousness on beliefs about sexuality, abortion, and suicide among groups with specific teachings and stronger norms on the issues (such as Christianity and Islam) and weaker impacts among other religions not preoccupied with these issues (such as Buddhism and Taoism). The patterns may even vary across sexuality versus sanctity-of-life issues within a single group if, as is the case among Jews, they have traditional teachings about sexuality but do not believe in an immortal soul.

Expectation 2: The relationship between religiousness and moral values varies across religious groups.

This study's overarching question is whether gender gaps in values would be differentand more consistent with our expectations based on positionality theories of structural disadvantage and political values - if the values-shaping power of religion were out of the picture. I expect religion to suppress gender difference in values under two conditions: (1) women being more religious than men and (2) religiousness being closely linked to traditional values. Past research has suggested these conditions will be present among Christians, where I expect religion to suppress gender differences in moral values. I do not expect religiousness to suppress gender differences in values, however, among groups where women are not more 
religious than men (which may be the case among Muslims) or where religiousness is less closely linked to conservative positions on sexuality and "sanctity" of life (which may be the case among Buddhists and Taoists).

Expectation 3: Religiousness suppresses what would otherwise be larger gender differences in values among some religious groups (including Christians) but not others (including Muslims).

\section{DATA, MEASURES, AND METHODS}

Data

The sixth wave (2010-2014) of the World Values Survey $(\mathrm{N}=85,181)$ provides data from a diverse set of 56 countries/regions across six continents that allow me to examine the interrelationships between gender, religion, and values worldwide. Despite concerns about surveys conducted in countries without a long history of survey research, these data-which intentionally cover a broader range of countries, including Muslim-majority countries, than other surveys - are the best available for examining variation between Muslims, Christians, and other religious groups around the world.

\section{Measures}

\section{Gender}

I proxy gender category (woman=1) using a measure in which interviewers were asked to "code respondent's sex by observation."

\section{Religiousness}

To arrive at the religiousness measure I present in the paper, I first conducted an exploratory factor analysis of the religiousness items included in the WVS and found strong support for a one 
factor solution. ${ }^{3}$ I also examined whether and how factor analysis varied across groups and generally found support for a single underlying factor of religiousness. ${ }^{4}$ I measure religiousness with a composite measure that aggregates six measures of religious salience and practice ( $a=.86)$ available in the World Values Survey. These items include importance of religion (not at all important $=1$ to very important $=4$ ) and of God in people's lives (not at all important $=1$ to very important=10), considering oneself a religious person (identity as an atheist $=1$, a not religious person $=2$, or a religious person $=3$ ), religious service attendance (never $=1$ to more than once a week=7), and prayer frequency (never=1 to several times a day=8). These items may best measure religiousness in the context of monotheistic and congregation-based religions—-such as Islam, Christianity, and Judaism - where "God" is a meaningful concept and attendance and prayer central religious practices. These items work well for measuring the majority of religious contexts, but are not as salient in some other contexts (e.g., Buddhism and Taoism). Therefore, although this study will examine patterns across groups, it will focus on the two largest religions — Christianity and Islam—where these items are particularly salient.

Due to differences in measurement across items, I standardized the items before aggregating. I then re-standardized the resulting scale so that it has a mean of 0 and a standard deviation of 1 . This approach is used for other composite measures in this study as well. Additional analyses with different measurement approaches and including different sets of items yield similar patterns, though focusing on measures of affective religion (e.g., prayer) tends to

\footnotetext{
${ }^{3}$ The eigenvalue for factor 1 was 2.7 and a second factor only .1, and the second factor simply loaded positively and weakly on the practice measures (attendance and prayer) and negatively and weakly on the other measures. ${ }^{4}$ Factor analysis among each of the religious groups provided support for the same one-factor solution. Inter-item correlation and Cronbach's alpha scores for the items were somewhat lower among Hindus, Buddhists, and Taoists than the other groups. Similar factor analysis and aggregation among just women and then among just men similarly provided support for the method I use. Therefore, although the items available in the WVS are not perfect, especially for considering religiousness among polytheists, they fit together very well and measure an underlying factor of religiousness that similarly applies to both women and men.
} 
emphasize women's religiousness whereas active involvement measures (e.g., attendance) tends to emphasize men's religiousness (see Sullins 2006). In order to encompass different aspects of religiousness that are more or less gender-typed to one gender or the other, I include each of these WVS religiousness measures. Table 1 presents descriptive statistics for the religiousness measure, as well as other measures used in this study.

\section{[Table-1]}

\section{Religious Group}

I measure religious group with an item that asks whether people belong to a religion and, if yes, which one. The standard set of religions on the instrument were Roman Catholic, Protestant, Orthodox, Jew, Muslim, Hindu, Buddhist, and Other (write in). Some countries included additional categories depending on their religious composition. This study puts particular attention on Muslims and Christians because they are the two largest groups, most countries are either predominantly Muslim or Christian, and the religiousness measures are equally relevant to these groups. I also include separate religious group categories for Jewish, Hindu, Buddhist, Taoist, and no affiliation. I combined other religious affiliations not included as categories across questionnaires, people who were asked the affiliation question but did not provide an answer, and people whose affiliation is simply listed as "other" into an encompassing "other" category that makes up $4 \%$ of the sample.

\section{Values}

This study focuses on key traditional moral values tied to specific religious mores on sexuality and the beginning and end of life, including the justifiability of (1) abortion, (2) premarital sex, (3) homosexuality, (4) suicide, and (5) euthanasia. Each of these items are measured from never justifiable $=1$ to always justifiable $=10$. These items address key moral values related to purity 
prohibitions regarding sexuality and "sanctity" of life—which are key aspects of the "traditional values" orientations in the Inglehart-Welzel (2005) cultural map — but are certainly not the only items that could be said to measure moral values (Hitlin and Vaisey 2013; Longest et al. 2013; Vaisey and Miles 2014). Therefore, as I will note in the results I considered a number of additional items, including additional measures related to sexuality (where the patterns are similar to those I present) and others related to separate values like redistribution (where the patterns differ). I also examine general political orientation to consider potential spillover from traditional moral values to more general politics (Miles and Vaisey 2015). For this item, respondents were asked to place their general political views on a scale from left to right (which I reverse code as right $=1$ to left $=10$ ).

\section{Covariates}

Individual-level covariates include age in decades (age in years/10), education (highest degree in six categories), and self-placement on a 10-point household income scale relative to other people in one's country. At the country-level, I include predominant religion (Muslim, Christian, or other/none, aggregated from the individual-level WVS data), logged per capita income adjusted for purchasing power (using UN data), and the KOF Globalization Index. This globalization index, which is commonly used in country-level research (e.g., Dreher, Gaston, and Martens 2008; Goryakina et al. 2015), covers economic (measured by sub-indices of economic flows and restrictions), social (measured by sub-indices of personal contact between countries, information flows, and cultural exchange), and political (sub-index of political embeddedness in global politics) dimensions of globalization. 


\section{Analytic Strategy}

This study first considers gender differences in religiousness by religious group, then the relationship between religiousness and values by religious group, and finally whether and how religiousness acts as an intermediary factor between gender and values across religious groups. All models are multilevel (individual and country levels) and use linear mixed-effects regression. Mediation/suppression is tested with a multilevel approach adapted from Krull and MacKinnon (2001) and implemented in Stata with a user-written program (ml_mediation) and bootstrapped errors (500 replications). This method computes the indirect effect (i.e., effect via mediator/suppressor) by regressing the dependent variable on the independent variable, the mediator/suppressor variable on the independent variable, and the dependent variable on the mediator and independent variables. These regressions adjust for covariates and the multilevel structure of the data.

I include the 56 countries/regions whose questionnaires included gender, religiousness items, and religious affiliation, and I focus on cases with complete information on gender and religiousness $(\mathrm{N}=85,181)$. When data are missing on categorical covariates, I create a missing category (see Table 1). When data are missing on continuous measures, I use regression-based multiple imputation (where the number of imputations equals 20). ${ }^{5}$ Sample sizes in any given analysis depend on the availability of its outcome measure (some items, including euthanasia and general political orientation, were not fielded in all countries). ${ }^{6}$

\footnotetext{
${ }^{5}$ Multilevel mediation tests use single imputation for compatibility with Stata ml_mediation user-written program.

${ }^{6}$ Additional analyses using survey weights yielded virtually identical results.
} 


\section{RESULTS}

Gender Differences in Religiousness across Groups and Contexts

Are gender differences in religiousness "universal," or do they vary across religious groups and contexts? Table 2 presents descriptive overviews of key measures across countries/regions. The countries/regions are sorted by size of gender differences in religiousness, starting with places where men are actually more religious than women. Men are significantly more religious than women in nine countries, all of which are predominantly Muslim. In fact, the first 12 countries listed are predominantly Muslim, and the last 21 are either predominantly Christian, Christian and unaffiliated, or currently majority unaffiliated but historically Christian. To further explore contextual variation, Figure A1 in the appendix presents gender differences in religiousness by proportion Muslim and proportion Christian. In countries with a higher proportion of Muslims men tend to be more religious, but in countries with more Christians women tend to be more religious than men. ${ }^{7}$ Gender differences in religiousness are clearly not universal and appear to be a function of particular religious systems.

\section{[Table-2]}

Turning to individual-level patterns, Table 3 presents gender differences in religiousness across religious groups. In Model 1, we see that women are .16 of a standard deviation more religious than men before accounting for religious group. This pattern is consistent with past research that suggests women are typically more religious than men. Model 2 controls for religious group and the gender difference in religiousness declines to .11 of a standard deviation. Model 3 interacts gender and religious group, demonstrating how gender differences in

\footnotetext{
${ }^{7}$ Proportion Muslim explains more of the country-level variation in gender differences in religiousness $\left(\mathrm{R}^{2}=.56\right)$ than proportion Christian $\left(\mathrm{R}^{2}=.36\right)$. Therefore, in terms of cross-national variation, the bigger distinction is between Muslims vs. all others than Christians vs. all others.
} 
religiousness vary across groups. With Muslim as the reference category, all interactions are positive and all but Jewish are significant (and this lack of significant difference is due to large standard errors resulting from there being only 189 Jews in the sample). Therefore, although men are more religious among Muslims,${ }^{8}$ among Jews and Taoists there are not significant gender differences in religiousness, among Hindus women are slightly more religious than men, and among Buddhists and Christians women are substantially more religious than men. Women are also substantially more religious than men among the unaffiliated, most of whom are in predominantly-Christian or historically-Christian contexts.

[Table-3]

Three-way interactions (not shown) between gender, religion, and religious context (i.e., predominant affiliation) demonstrate that gender differences in religiousness vary across both religious groups and religious contexts. Muslim men are more religious than Muslim women in Muslim contexts, but there are different patterns among Muslims in predominantly-Christian and other non-Muslim-majority contexts. These patterns of contextual variation are illustrated in Figure 1, which presents gender differences in religiousness across various subgroups. ${ }^{9}$ Not only are Muslim men not more religious than Muslim women in Christian contexts, but these Muslims in Christian contexts actually demonstrate patterns more similar to Christians, with Muslim women significantly more religious than Muslim men. Among the unaffiliated, women

\footnotetext{
${ }^{8}$ Consistent with Sullins (2006), men's greater religiousness among Muslims is particularly pronounced on measures of active religiousness (i.e., attendance), which are then particularly closely related to political values. This pattern is consistent with previous work suggesting that gender differences in religiousness are, at least in part, a function of gendered expectations in relation to religion (Schnabel et al. 2018). For example, due to gendered religious norms, which appear to be most salient in Muslim-majority societies, Muslim men attend services at a mosque more often than Muslim women do in Muslim-majority societies.

${ }^{9}$ I only present contextual variation for some groups because other groups are only present in these data in large enough numbers to examine in one type of context where they are either a minority or the majority. For example, as these data do not include Israel, all Jews are minority-context Jews. Moreover, the vast majority of Hindus in the sample (89\%) live in India.
} 
are more religious than men across contexts, but the size of the gap is somewhat larger in Christian contexts - where the unaffiliated are most likely to be former Christians and/or hold some Christian beliefs - than in other contexts. Christians demonstrate similar gender differences in religiousness across Christian, Muslim, and other contexts. Christians vary, however, by tradition and regional context. For example, there are larger gender differences among Orthodox Christians than among Catholics and Protestants.

[Figure-1]

Similar to non-Christians, Christians outside the West (i.e., outside Western Europe and English-speaking North America and Australasia) have been understudied. I examined whether gender differences in religiousness vary in non-Western vs. Western contexts, and also considered the patterns for Sub-Saharan Africa where a rapidly growing proportion of the world's Christians are located. Gender differences in religiousness among Christians are somewhat smaller in non-Western contexts than in Western contexts. The large gender differences among Eastern Orthodox Christians, however, mask what would otherwise be larger variation between East and West. In Sub-Saharan Africa, for example, gender differences in religiousness among Christians are much smaller than among Christians in the West. In support of expectation 1, gender differences in religiousness vary across religious groups and contexts. Women are more religious than men among some groups (including Christians and also Buddhists and the unaffiliated) but not others (including Muslims and also Jews and Taoists). And these patterns vary across religiocultural contexts, with, for example, the Muslim pattern of men being more religious than women being specific to Muslim-majority contexts and reversed in Christian-majority contexts where Muslims demonstrate a pattern more similar to the majority religious group. 


\section{Religiosity and Values across Groups and Contexts}

Having seen that gender differences in religiousness vary across religious groups and contexts, we now turn to the questions of whether and how religiousness shapes gender differences in values, and whether and how the patterns vary across religious groups. The next step is to consider whether and how religiousness relates to values across religious groups. We might take for granted that greater religiousness is linked to more traditional or conservative values, but even if most religions tend to have teachings that get established in a particular point in time, traditional norms that harken to the past, or even "eternal truths" antithetical to social change, not all religions have the same teachings and we might expect the relationship between religiousness and particular values to vary across groups.

As Table 4 shows, religiousness is closely linked to conservative values across issues for the full sample, with a stronger link between religiousness and particular issues related to sexuality and beginning-and-end-of-life issues than general political orientation. Strong for the sample as a whole, these relationships vary across groups. Among Muslims the relationships are consistent but weaker than for the full sample, whereas among Christians they are consistent and stronger. Among Jews, religiousness is linked to more conservative views on sexuality, but not on end-of-life issues (of note, Judaism does not place emphasis on an immortal soul like Islam and Christianity). Religiousness is a strong factor in these values for Hindus, but the link is weaker among Buddhists. Among Taoists there is not a strong link between religiousness as measured in the WVS and these issues, and the coefficients for sexuality issues are actually reversed. Although the unaffiliated are obviously much less religious overall, variation in religiousness among them is still important in predicting values. Across the major groups considered in this study, the relationship between religiousness and moral values varies, but 
among most groups more religiousness is strongly linked with more traditional stances on issues of sexuality and sanctity of life. There is some spillover into general political orientation as well.

[Table-4]

Table 4 also considers further variation, presenting patterns for the three major Christian traditions (Catholic, Orthodox, and Protestant) and contextual variation for the three largest groups (Muslims, Christians, and the unaffiliated). These results demonstrate that religiousness tends to be more important for people's values on specific issues tied to religious teachings when they are religious minorities rather than part of the religious majority (especially among Muslims), but that does not spill over to greater differences in partisanship among religious minorities (which might be a function of a their sense of being part of a minority group, which could counteract some of the influence of religiousness on general partisanship). Finally, religiousness matters more for the unaffiliated in Christian contexts than in other contexts.

Consistent with expectation 2, the impact of religiousness on values varies across religious groups and contexts, with particularly strong impact on Christians and to a lesser extent Muslims, and more impact on people where they are a religious minority.

\section{Impact of Religiosity on Gender Differences in Values}

Table 5 presents gender differences in beliefs about the justifiability of abortion (never justifiable $=1$ to always justifiable $=10$ ) — a key moral issue closely related to religious norms among many religious groups_- before and after accounting for religiousness. In this table I present patterns for the full sample and the three largest religious groups, and will later present summary patterns for additional groups. In the full sample, women are somewhat more supportive of abortion than men and religiousness suppresses what would otherwise be larger gender differences in support for the justifiability of abortion (i.e., women would be even more 
likely to support it in comparison to men). This pattern extends from the full sample to Christians (among whom there is a .08 gender gap before accounting for religiousness and .27 after). Similar to the pattern among Christians, the unaffiliated would demonstrate larger gender differences in abortion attitudes if not for religiousness. ${ }^{10}$ Among Muslims, however, the pattern is reversed. The gender gap among Muslims starts out larger (.21), but after accounting for religiousness the gap is reduced (.14).

[Table-5]

Multilevel mediation tests demonstrate that the suppression by religiousness of gender differences in abortion attitudes among the full sample, among Christians, and among the unaffiliated, as well as mediation of gender differences among Muslims, are all significant. The patterns for abortion attitudes, therefore, support expectation 3: Religiousness suppresses gender differences in values among Christians but not Muslims, which then makes it so that gender differences in political values are larger-and closer to what we would expect based on positionality theories of political values - among Muslims than Christians. In fact, not only does religiousness suppress gender differences in values among Christians, but it amplifies gender differences in values among Muslims. In other words, were it not for religiousness, Christian women would be even more liberal than Christian men and Muslim men would not be so much more conservative than Muslim women.

\footnotetext{
10 The unaffiliated are a diverse group among whom factors that were less important for differentiating among people in other groups are more important. For example, among the unaffiliated those with a low level of education are very different from those with a high level of education. And whereas globalization was not as important a factor for other groups, unaffiliated people in more globalized contexts are very different from those who say they are unaffiliated in less globalized contexts. One possibility is that in some contexts the unaffiliated are people who simply do not see their beliefs and practices as religion or do not fit with proffered religious categories, whereas in others the unaffiliated are more consciously secular.
} 
Having examined the patterns for the full sample and three key groups on one key issue (abortion), we now turn to summary patterns for more sexuality measures across a broader range of groups. Table 6 shows that while religiousness suppresses or amplifies gender differences among Christians and Muslims, it does not have much of an impact on gender differences in abortion attitudes among other groups. Religiousness does not greatly alter gender differences in abortion attitudes among Jews and Hindus because gender differences in religiousness are generally small among these groups. Gender differences in religiousness are larger among Buddhists than Jews or Hindus, but the link between religiousness and abortion attitudes is weaker. Therefore, religiousness does not significantly alter gender differences in abortion attitudes among Buddhists. Among Taoists, gender differences in religiousness are small and there is not a relationship between religiousness and abortion attitudes, and therefore religiousness does not impact gender differences in Taoists' abortion attitudes.

\section{[Table-6]}

Looking at the results for the full sample, religiousness intermediates the relationship between gender and values on premarital sex and homosexuality in addition to abortion. On premarital sex, women are more conservative than men overall and religiousness helps explain why. Consistent with the patterns for abortion attitudes, religiousness suppresses what would otherwise be more liberalness among women (and thus, in these cases where men are typically more liberal, smaller gender differences). Among Muslims, however, we again see men's greater religiousness keeping women more liberal than they might otherwise be in comparison to men. Whereas women are more opposed to premarital sex overall, they are more supportive of sexual minorities. And, if it were not for women's greater overall religiousness, this gender gap would be even larger with women even more accepting. Again we see the same type of variation in the 
patterns across groups. For example, religion suppresses what would otherwise be even larger gender differences among the full sample, Christians, and the unaffiliated. Among Muslims, however, religiousness amplifies what would otherwise be smaller gender differences. Among other religious groups, accounting for religiousness does not have a strong impact on gender differences in attitudes toward homosexuality.

Looking at the additional subgroups included in Table 6, we see that although the magnitude of some of the relationships vary across major Christian groups (Catholics, Orthodox, and Protestants), the same general pattern appears across these Christian groups where women are consistently more religious than men and religiousness consistently suppresses what would otherwise be larger gender differences in values. Of note, gender differences in religiousness tend to be larger among the Orthodox but the relationship between religiousness and values tends to be weaker, and therefore the comparative impact of religiousness in suppressing gender differences in values tends to be similar among the Orthodox as among Catholics and Protestants.

The patterns do not vary substantially among Christians in different contexts, but context is very important for Muslims: religiousness amplifies gender differences in values in Muslimmajority contexts, but not in non-Muslim contexts. In fact, the non-significant trend among minority Muslims is toward religiousness suppressing women's liberal abortion attitudes. Because religiousness amplifies gender differences among majority Muslims but not minority Muslims, gender differences in values are larger among majority Muslims than minority Muslims before accounting for religiousness. Minority Muslims, therefore, demonstrate patterns more similar to the religious cultures in which they live. 
Shifting from sexuality and beginning-of-life issues to end-of-life issues, Table 7 presents attitudes toward suicide and euthanasia (never justifiable $=1$ to always justifiable $=10$ ). It also presents patterns for political orientation (right=1 to left=10) to consider potential spillover from specific traditional moral values into general partisanship. In the full sample, women are more opposed to suicide than are men. But after accounting for religiousness, women are no longer more opposed to suicide. And, once again, we see similar patterns of variation across religious groups. Muslim women start out more liberal than Christian women in relation to comparable men, but accounting for religiousness shows that religiousness was suppressing gender differences among Christians and amplifying gender differences among Muslims. On euthanasia, which was not asked in as many countries, there are not gender differences before accounting for religiousness, except among Muslims where women are more liberal than men. But after accounting for religiousness, women are generally more liberal than men among the full sample and Christians, whereas Muslim women's comparatively greater liberalness is attenuated. Also similar to the patterns for the sexuality-related issues presented earlier, religiousness does not substantially alter gender differences in end-of-life values among religions besides Islam and Christianity.

[Table-7]

Table 7 also presents gender differences in general political orientation. Women are more likely to identify as liberal than men, but this gender difference would be significantly larger if not for religiousness. And we again see variation across religious groups with Muslim women being more liberal than Muslim men before accounting for religiousness (but not after), and Christian women not more liberal before accounting for religiousness (but significantly more liberal after). Similar to the findings for specific moral issues, religiousness also suppresses 
gender differences in partisanship among the unaffiliated, but not other religious groups.

Mediation tests again demonstrate significance in the suppression of gender differences in political orientation among the full sample, Christians, and the unaffiliated, and the mediation of gender differences among Muslims.

The patterns for specific issues and for general political orientation support expectation

\section{3: Religiousness suppresses gender differences in values among Christians but not Muslims. In} fact, religiousness amplifies gender differences in values among Muslims. In other words, were it not for religiousness, Christian women would be even more liberal than Christian men and Muslim men would not be so much more conservative than Muslim women. This general variation does not tell the full story, however: whereas religiosity amplifies gender differences in values among Muslims in Muslim-majority contexts where men are more religious than women, it is not strongly implicated in gender differences in values among minority Muslims.

Subsequently, gender differences in values are larger among Muslims in Muslim-majority contexts than among Christians and, on some issues including abortion, Muslims in Muslimminority contexts.

Additional analyses considered more issues closely tied to religious strictures and other issues less closely tied to traditional religious mores. The patterns presented in this study are specific to the types traditional moral issues presented above. On issues such as divorce and prostitution where there are strong religious norms among monotheists and some other religious groups, the patterns are similar to those presented in the paper. But on issues less closely tied to religious beliefs and norms, religion does not greatly alter gender differences in values. On attitudes toward economic inequality, for example, religiousness does not suppress gender differences in attitudes among the full sample (nor does it do so among specific religious groups) 
(see Davis and Robinson 2006 on how religion can be linked to progressive economics).

Therefore, this study's finding that religion suppresses liberal views appears to be a function of religion's symbolic power in shaping attitudes toward certain traditional moral issues such as sexuality and suicide. While there is some spillover into more general political orientation, religion does not have as strong an impact on issues not closely tied to specific religious norms.

\section{Summary}

Women are more religious than men among some groups (including Christians) but not others (including Muslims in Muslim-majority countries) (which supports expectation 1); religiosity has differential impacts on traditional moral values across religious groups with stronger conservatizing influence on Christians and Muslims than Buddhists and Taoists (which supports expectation 2); and religion suppresses gender differences in values among Christians but amplifies gender differences among Muslims in Muslim-majority countries (which supports expectation 3). Religiosity, therefore, does not have universal impacts: different religions —as complex social institutions with distinct characteristics and norms_-produce different social consequences across groups and contexts. On issues where religious teachings and norms are closely linked to values — such as questions regarding sexual morality and sanctity of lifewomen's greater religiousness among Christians suppresses what would otherwise be substantially larger gender differences. And, among Muslims, men's greater religiousness in Muslim-majority contexts amplifies what would otherwise be smaller gender differences. The unaffiliated tend to demonstrate patterns similar to Christians, especially when in Christian contexts, but religiousness does not have a strong impact on gender differences in values among other religious groups where gender differences in religiousness are smaller and/or there are weaker relationships between religiousness and traditional moral values. In short, gender gaps in 
values would be different in ways that vary across religious groups if the values-shaping power of religions were out of the picture.

\section{DISCUSSION}

Gender differences in values have been commonly found across the social sciences. Women tend to be more liberal than men, supporting more egalitarian policies and voting for more progressive politicians. But on some issues women are no more liberal than men, and on certain values related to traditional morality women are even more conservative than men (at least in the United States where most of the gender gap in values research has been conducted). This study examined the interrelationship between gender, religion, and views on sexuality and the beginning and end of life cross-nationally, demonstrating that religion complicates the relationship between gender and values. Specifically, religion generally suppresses what would otherwise be larger and more consistent gender differences in values. But this pattern varies across groups, and is most prominent among Christians and the religiously unaffiliated. Among Muslims, religion actually amplifies gender differences in values, which would be smaller if it were not for men's greater religiousness. This pattern is most prominent in majority-Muslim contexts where Muslim men are substantially more religious than Muslim women. Among other religious groups, religiousness does not substantially alter gender differences in values.

Much of what we know about religion is a result of examining Christians in Christian contexts, and therefore many widely-assumed patterns could be specific to Christians. But religions are complex social institutions with distinct social consequences. Women being more religious than men is pronounced among Christians but generally reversed among Muslims in Muslim countries, and the phenomenon of women being more liberal than men is subsequently more pronounced among Muslims in Muslim countries. Whereas religiousness suppresses 
gender differences in values and political orientation among Christians, it amplifies gender differences among majority Muslims. Religiousness also suppresses gender differences in values among the unaffiliated, who are disproportionately located in historically-Christian contexts and many of whom hold some Christian beliefs and/or used to be Christian. Religiousness does not, however, do much to intermediate the relationship between gender and traditional moral values among other groups including Hindus, Buddhists, Taoists, and minority Muslims. These findings highlight the importance of broader examinations that look beyond the Western and predominantly Christian contexts social scientific research typically focuses on.

This study could have focused solely on the general pattern across all subjects rather than considering variation in the patterns for gender and values across religious groups. The finding would have been that women tend to be more religious than men, and that religiousness suppresses what would otherwise be larger gender differences in values. Such a study would have helped explain the gender-and-politics underdog paradox present in the United States and some other contexts, but it would have missed a key part of the story: the exact opposite pattern is true among Muslims, the world's second largest religious group where religiousness actually amplifies rather than suppresses gender differences in values. As illustrated by the distinct social consequences of different religions, we may want to move away from looking at the impact of religion generally to looking at the impact of particular religions and shift from talking about the study of "religion" to the study of "religions." Just as general social science should move beyond the West, social science of religions should move beyond Christianity. Given its size as the world's second-largest religion, Islam is particularly understudied.

Although the WVS data used in this study covered more countries than other data sources, Israel was not included and, therefore, the comparison for how patterns varied across the 
major monotheistic religions was limited. Not only was the sample size of Jews small, but this study could only examine Jews where they are the minority. A recent study suggested that Jewish men are more religious than Jewish women in Israel (Schnabel et al. 2018) despite not necessarily being more religious in other contexts (Schnabel 2015), and future research should consider whether this Israel-specific gender gap in religiousness amplifies gender differences in values similar to the parallel gender gap among majority Muslims in this study. Future research should also further parse variation across other religious groups - perhaps with other measures of religiousness less tied to monotheistic religions - and consider whether the patterns demonstrated in this study vary by class, race, or other factors. Another potential limitation is the question about data quality in contexts without a long history of survey research. I checked the general patterns with data from the 2008 religion module of the International Social Survey Programme. These analyses confirmed that religion suppresses gender differences in values among Christians, and the patterns among Muslims were consistent with the present study. But these data do not include a sufficient number of Muslim contexts for a full comparison between the two datasets. ${ }^{11}$ Therefore, future research should put the findings from this study to the test as additional data on Muslim and other non-Christian contexts become available.

Religions have important societal implications, such as complicating the relationship between gender and values. But the social consequences of religions are tradition- and contextdependent, with consistent patterns that may seem like "social facts" in one tradition or context—-such as gender differences in religiousness — not generalizing globally. In the Christian West, women are more religious than men and religiousness is closely linked to conservative moral values, leading to the suppression of what would otherwise be larger gender differences in

\footnotetext{
11 Turkey is the only Muslim-majority country in the ISSP dataset, and two-thirds of the Muslims in that dataset live
} 
values. But among Muslims in Muslim countries, religiousness amplifies what would otherwise be smaller gender differences in values. A subsequent social consequence of religions, therefore, is that gender differences in values tend to be larger among Muslims than among Christians.

Future research should further examine the societal implications of religions and whether and how they vary. Speaking to both social scientists generally and social scientists of religions more specifically, we should broaden our scope and reexamine whether established "social facts" are global human phenomena or idiosyncrasies of the Christian West.

\section{APPENDIX}

[Figure-A1]

in Turkey. 


\section{REFERENCES}

Adamczyk, Amy. 2017. Cross-National Public Opinion about Homosexuality: Examining Attitudes across the Globe. Berkeley: University of California Press.

Adamczyk, Amy, Katharine Boyd, and Brittany Hayes. 2016. "Place Matters: Contextualizing the Roles of Religion and Race for Understanding Americans' Attitudes about Homosexuality." Social Science Research 57(1):1-16.

Adamczyk, Amy and Brittany Hayes. 2012. "Religion and Sexual Behaviors: Understanding the Influence of Islamic Cultures and Religious Affiliation for Explaining Sex Outside of Marriage." American Sociological Review 77(5):723-46.

Adamczyk, Amy and Cassady Pitt. 2009. "Shaping Attitudes about Homosexuality: The Role of Religion and Cultural Context." Social Science Research 38(2):338-51.

Agadjanian, Victor. 2015. "Women's Religious Authority in a Sub-Saharan Setting: Dialectics of Empowerment and Dependency." Gender \& Society 29(6):982-1008.

Avishai, Orit. 2008. “'Doing Religion” in a Secular World: Women in Conservative Religions and the Question of Agency." Gender \& Society 22(4):409-33.

Barkan, Steven. 2014. “Gender and Abortion Attitudes.” Public Opinion Quarterly 78(4):94050.

Bartkowski, John and Jen'nan Ghazal Read. 2003. "Veiled Submission: Gender, Power, and Identity among Evangelical and Muslim Women in the United States." Qualitative Sociology 26(1):71-92.

Beit-Hallahmi, Benjamin. 2014. Psychological Perspectives on Religion and Religiosity. New York: Routledge.

Beutel, Ann and Margaret Mooney Marini. 1995. "Gender and Values.” American Sociological Review 60(3):436-48.

Blekesaune, Morten and Jill Quadagno. 2003. "Public Attitudes toward Welfare State Policies." European Sociological Review 19(5):415-27.

Du Bois, W. E. B. 1903. The Souls of Black Folk. Chicago: A. C. McClurg \& Co.

Box-Steffensmeier, Janet, Suzanna DeBoef, and Tse-min Lin. 2004. "Dynamics of the Partisan Gender Gap.” American Political Science Review 98(3):515-28.

Burke, Kelsy. 2012. “Women's Agency in Gender-Traditional Religions.” Sociology Compass 6(2):122-33.

Cadge, Wendy, Peggy Levitt, and David Smilde. 2011. "De-Centering and Re-Centering: Rethinking Concepts and Methods in the Sociological Study of Religion." Journal for the Scientific Study of Religion 50(3):437-49. 
Cassese, Erin and Mirya Holman. 2016. "Religious Beliefs, Gender Consciousness, and Women's Political Participation.” Sex Roles 75(9-10):514-27.

Cassese, Erin and Mirya Holman. 2017. "Religion, Gendered Authority, and Identity in American Politics." Politics and Religion 10(1):31-56.

Charrad, Mounira. 2011. "Gender in the Middle East: Islam, State, Agency." Annual Review of Sociology 37(1):417-37.

Collins, Patricia Hill. 2000. Black Feminist Thought. New York: Routledge.

Conover, Pamela Johnston. 1988. "Feminists and the Gender Gap." The Journal of Politics 50(4):985-1010.

Davenport, Lauren. 2016. "Beyond Black and White: Biracial Attitudes in Contemporary U.S. Politics.” American Political Science Review 110(1):52-67.

Davis, Angela. 1971. Lectures on Liberation. Los Angeles: National United Committee to Free Angela Davis.

Davis, Nancy and Robert Robinson. 1991. 'Men's and Women's Consciousness of Gender Inequality." American Sociological Review 56(1):72-84.

Davis, Nancy and Robert Robinson. 2006. "The Egalitarian Face of Islamic Orthodoxy: Support for Islamic Law and Economic Justice in Seven Muslim-Majority Nations.” American Sociological Review 71(2):167-90.

Dreher, Axel, Noel Gaston, and Pim Martens. 2008. Measuring Globalisation. New York: Springer.

Eagly, Alice, Amanda Diekman, Mary Johannesen-Schmidt, and Anne Koenig. 2004. "Gender Gaps in Sociopolitical Attitudes." Journal of Personality and Social Psychology 87(6):796816.

Edgell, Penny. 2006. Religion and Family in a Changing Society. Princeton, NJ: Princeton University Press.

Edgell, Penny. 2012. “A Cultural Sociology of Religion: New Directions.” Annual Review of Sociology 38(1):247-65.

Edgell, Penny and Danielle Docka. 2007. "Beyond the Nuclear Family? Familism and Gender Ideology in Diverse Religious Communities." Sociological Forum 22(1):25-50.

Edgell, Penny, Jacqui Frost, and Evan Stewart. 2017. "From Existential to Social Understandings of Risk: Examining Gender Differences in Non-Religion.” Social Currents 4(6):556-74.

Finke, Roger and Amy Adamczyk. 2008. "Cross-National Moral Beliefs: The Influence of National Religious Context.” Sociological Quarterly 49(4):617-52. 
Francis, Leslie and Carolyn Wilcox. 1998. "Religiosity and Femininity: Do Women Really Hold a More Positive Attitude toward Christianity?" Journal for the Scientific Study of Religion 37(3):462-69.

Goryakina, Yevgeniy, Tim Lobsteinc, Philip James, and Marc Suhrcke. 2015. "The Impact of Economic, Political and Social Globalization on Overweight and Obesity in the 56 Low and Middle Income Countries." Social Science \& Medicine 133(1):67-76.

Hackett, Conrad, Caryle Murphy, and David McClendon. 2016. The Gender Gap in Religion around the World. Washington, D.C.: Pew Research Center.

Hadler, Markus. 2012. "Influence of World Societal Forces on Social Tolerance." Sociological Quarterly 53(2):211-37.

Hastings, Orestes P. and D.Michael Lindsay. 2013. "Rethinking Religious Gender Differences: The Case of Elite Women." Sociology of Religion 74(4):471-95.

Herek, Gregory. 2002. "Gender Gaps in Public Opinion about Lesbians and Gay Men.” Public Opinion Quarterly 66(1):40-66.

Hitlin, Steven and Stephen Vaisey. 2013. "The New Sociology of Morality." Annual Review of Sociology 39(1):51-68.

Hoffman, Martin. 2000. Empathy and Moral Development: Implications for Caring and Justice. Cambridge: Cambridge University Press.

Hoffmann, John. 2009. “Gender, Risk, and Religiousness: Can Power Control Provide the Theory?" Journal for the Scientific Study of Religion 48(2):232-40.

Hout, Michael and Claude Fischer. 2014. "Explaining Why More Americans Have No Religious Preference: Political Backlash and Generational Succession, 1987-2012." Sociological Science 1(October):423-47.

Hughes, Michael and Steven Tuch. 2003. "Gender Differences in Whites' Racial Attitudes." Social Psychology Quarterly 66(4):384-401.

Hunt, Matthew. 1996. "Individual, Society, or Both? A Comparison of Black, Latino, and White Beliefs about Causes of Poverty." Social Forces 75(1):293-322.

Inglehart, Ronald and Pippa Norris. 1999. "The Developmental Theory of the Gender Gap: Women and Men's Voting Behavior in Global Perspective." International Political Science Review 21(4):441-63.

Inglehart, Ronald and Christian Welzel. 2005. Modernization, Cultural Change, and Democracy. Cambridge: Cambridge University Press.

Jost, John et al. 2014. "Belief in a Just God (and a Just Society): A System Justification Perspective on Religious Ideology." Journal of Theoretical and Philosophical Psychology 34(1):56-81.

Junge, Daniel and Bryan Storkel. 2014. Fight Church. United States: LionsGate Entertainment. 
Khurshid, Ayesha. 2015. "Islamic Traditions of Modernity: Gender, Class, and Islam in a Transnational Women’s Education Project.” Gender \& Society 29(1):98-121.

Kniss, Fred. 2014. "Against the Flow: Learning from New, Emergent, and Peripheral Religious Currents.” Sociology of Religion 75(3):351-66.

Krull, Jennifer and David MacKinnon. 2001. "Multilevel Modeling of Individual and Group Level Mediated Effects." Multivariate Behavioral Research 36(2):249-77.

Kucinskas, Jaime. 2010. “A Research Note on Islam and Gender Egalitarianism: An Examination of Egyptian and Saudi Arabian Youth Attitudes." Journal for the Scientific Study of Religion 49(4):761-70.

Longest, Kyle, Steven Hitlin, and Stephen Vaisey. 2013. "Position and Disposition: The Contextual Development of Human Values.” Social Forces 91(4):1499-1528.

Manza, Jeff and Clem Brooks. 1998. "The Gender Gap in U.S. Presidential Elections.” American Journal of Sociology 103(5):1235-1266.

Marx, Karl. 1970. Marx's Critique of Hegel's Philosophy of Right. Cambridge: Cambridge University Press.

McDermott, Monika. 2016. Masculinity, Femininity, and American Political Behavior. New York: Oxford University Press.

Messner, Michael. 2013. "The Masculinity of the Governator: Muscle and Compassion in American Politics." Gender \& Society 21(4):461-80.

Miles, Andrew and Stephen Vaisey. 2015. "Morality and Politics: Comparing Alternate Theories.” Social Science Research 53:252-69.

Miller, Alan and Rodney Stark. 2002. "Gender and Religiousness: Can Socialization Explanations Be Saved?” American Journal of Sociology 107(6):1399-1423.

Norris, Pippa and Ronald Inglehart. 2008. "Existential Security and the Gender Gap in Religious Values (Unpublished Working Paper)."

Norris, Pippa and Ronald Inglehart. 2011. Sacred and Secular: Religion and Politics Worldwide. 2nd ed. New York: Cambridge University Press.

Olson, Laura, Wendy Cadge, and James Harrison. 2006. "Religion and Public Opinion about Same-Sex Marriage.” Social Science Quarterly 87(2):340-60.

Pratto, Felicia, Lisa Stallworth, and Jim Sidanius. 1997. "The Gender Gap: Differences in Political Attitudes and Social Dominance Orientation.” British Journal of Social Psychology 36:49-68.

Prickett, Pamela. 2015. "Negotiating Gendered Religious Space: Particularities of Patriarchy in an African American Mosque." Gender \& Society 29(1):51-72. 
Putnam, Robert and David Campbell. 2010. American Grace: How Religion Divides and Unites Us. New York: Simon \& Schuster.

Rankin, Lindsay, John Jost, and Cheryl Wakslak. 2009. "System Justification and the Meaning of Life: Are the Existential Benefits of Ideology Distributed Unequally across Racial Groups?" Social Justice Research 22(2-3):312-33.

Rao, Aliya Hamid. 2015. "Gender and Cultivating the Moral Self in Islam: Muslim Converts in an American Mosque." Sociology of Religion 76(4):413-35.

Read, Jen'nan Ghazal and David Eagle. 2014. "Intersectionality and Identity: An Exploration of Arab American Women.” Pp. 75-96 in Religion and Inequality in America: Research and Theory on Religion's Role in Stratification, edited by Lisa Keister and Darren Sherkat. Cambridge: Cambridge University Press.

Rinehart, Sue Tolleson and Jerry Perkins. 1989. "The Intersection of Gender Politics and Religious Beliefs.” Political Behavior 11(1):33-56.

Robinson, Robert and Wendell Bell. 1978. "Equality, Success, and Social Justice in England." American Sociological Review 43(2):125-43.

Samuel, Geoffrey. 2011. "Islamic Piety and Masculinity." Contemporary Islam 5(3):309-22.

Schnabel, Landon. 2015. "How Religious Are American Women and Men? Gender Differences and Similarities.” Journal for the Scientific Study of Religion 54(3):616-22.

Schnabel, Landon. 2016a. "Religion and Gender Equality Worldwide: A Country-Level Analysis." Social Indicators Research 129(2):893-907.

Schnabel, Landon. 2016b. "The Gender Pray Gap: Wage Labor and the Religiosity of HighEarning Women and Men.” Gender \& Society 30(4):643-69.

Schnabel, Landon. 2017. “Gendered Religiosity.” Review of Religious Research 59(4):547-56.

Schnabel, Landon. 2018. "Sexual Orientation and Social Attitudes.” Socius 4:1-18.

Schnabel, Landon, Conrad Hackett, and David McClendon. 2018. "Where Men Appear More Religious than Women: Turning a Gender Lens on Religion in Israel." Journal for the Scientific Study of Religion In Press.

Schuman, Howard and John Harding. 1963. "Sympathetic Identification with the Underdog." Public Opinion Quarterly 27(2):230-41.

Shapiro, Robert and Harpreet Mahajan. 1986. "Gender Differences in Policy Preferences." Public Opinion Quarterly 50(1):42.

Sherkat, Darren, Kylan Mattias de Vries, and Stacia Creek. 2010. "Race, Religion, and Opposition to Same-Sex Marriage.” Social Science Quarterly 91(1):80-98.

Sidanius, Jim and Felicia Pratto. 1999. Social Dominance: An Intergroup Theory of Social Hierarchy and Oppression. New York: Cambridge University Press. 
Sidanius, Jim, Felicia Pratto, and Lawrence Bobo. 1994. "Social Dominance Orientation and the Political Psychology of Gender.” Journal of Personality and Social Psychology 67(6):9981011.

Simmel, Georg. 1950. The Sociology of Georg Simmel. edited by Kurt Wolff. Glencoe: Free Press.

Smilde, David and Matthew May. 2015. "Causality, Normativity, and Diversity in 40 Years of U.S. Sociology of Religion.” Sociology of Religion 76(4):369-88.

Smith, Christian et al. 2013. "Roundtable on the Sociology of Religion: Twenty-Three Theses on the Status of Religion in American Sociology." Journal of the American Academy of Religion 81(4):903-38.

Stark, Rodney. 2002. "Physiology and Faith: Addressing the 'Universal' Gender Difference in Religious Commitment." Journal for the Scientific Study of Religion 41(3):495-507.

Stevens, Mitchell, Cynthia Miller-Idriss, and Seteney Shami. 2018. Seeing the World: How US Universities Make Knowledge in a Global Era. Princeton: Princeton University Press.

Stewart, Evan, Jacqui Frost, and Penny Edgell. 2017. "Intersectionality and Power." Secularism \& Nonreligion 6(6):1-3.

Sullins, D.Paul. 2006. "Gender and Religion: Deconstructing Universality, Constructing Complexity.” American Journal of Sociology 112(3):838-80.

Vaisey, Stephen and Andrew Miles. 2014. "Tools from Moral Psychology for Measuring Personal Moral Culture." Theory and Society 43(3/4):311-32.

de Vaus, David and Ian McAllister. 1987. "Gender Differences in Religion: A Test of the Structural Location Theory.” American Sociological Review 52(4):472-81.

Wilcox, Clyde. 1992. "Race, Religion, Region and Abortion Attitudes." Sociology of Religion 53(1):97.

Wilde, Melissa and Lindsay Glassman. 2016. "How Complex Religion Can Improve Our Understanding of American Politics.” Annual Review of Sociology 42(1):407-25.

Winter, Nicholas. 2010. "Masculine Republicans and Feminine Democrats: Gender and Americans' Explicit and Implicit Images of the Political Parties." Political Behavior 32:587-618. 
Gender Differences in Values 39

\section{TABLES AND FIGURES}

Table 1: Descriptive Statistics

\begin{tabular}{|c|c|c|c|c|c|}
\hline Measures & Metric & $N$ & $\begin{array}{c}\text { Mean/ } \\
\text { Proportion }\end{array}$ & SD & Range \\
\hline Gender & Woman=1 & 85,181 & .52 & & \\
\hline Religiousness & 5-item Scale; $a=.86$ & 85,181 & .00 & 1.00 & $-2.90-1.52$ \\
\hline Religious Group & Religious Affiliation & 85,181 & & & \\
\hline Muslim & Muslim=1 & & .26 & & \\
\hline Christian & Christian $=1$ & & .40 & & \\
\hline Jewish & Jewish $=1$ & & .00 & & \\
\hline Hindu & Hindu $=1$ & & .06 & & \\
\hline Buddhist & Buddhist $=1$ & & .05 & & \\
\hline Taoist & Taoist $=1$ & & .00 & & \\
\hline No Affiliation & Religiously Unaffiliated=1 & & .19 & & \\
\hline Other/Missing & Other Affiliation or Missing=1 & & .04 & & \\
\hline \multicolumn{6}{|l|}{ Individual-Level Covariates } \\
\hline Age & In Decades (Age in Years/10) & & 4.23 & 1.66 & $1.6-9.9$ \\
\hline Education & Highest Degree & 85,181 & & & \\
\hline Primary or Less & Primary or Less $=1$ & & .23 & & \\
\hline Incomplete Secondary & Incomplete Secondary $=1$ & & .15 & & \\
\hline Complete Secondary & Complete Secondary=1 & & .36 & & \\
\hline Some College & Some College $=1$ & & .08 & & \\
\hline College Degree & College Degree $=1$ & & .17 & & \\
\hline Missing & Missing $=1$ & & .01 & & \\
\hline Income Scale (Self-Placement) & Lowest Income $=1$ to Highest $=10$ & & 4.82 & 2.10 & $1-10$ \\
\hline \multicolumn{6}{|l|}{ Country-Level Covariates } \\
\hline Predominant Affiliation & & 85,181 & & & \\
\hline Muslim & Majority of Population is Muslim & & .25 & & \\
\hline Christian & Majority of Population is Christian & & .49 & & \\
\hline Other or No Majority & Other Majority or No Majority & & .26 & & \\
\hline Logged Per Capita PPP GDP & Country Values (56 countries) & 85,181 & .00 & 1.00 & $-.85-2.98$ \\
\hline Globalization Index & No Globalization $=0$ to Full $=100$ & 85,181 & 63.95 & 12.43 & $40.22-91.24$ \\
\hline \multicolumn{6}{|l|}{ Values } \\
\hline Justifiability of Abortion & Never Justifiable $=1$ to Always $=10$ & 82,180 & 3.27 & 2.78 & $0-10$ \\
\hline Justifiability of Premarital Sex & Never Justifiable $=1$ to Always $=10$ & 75,587 & 4.57 & 3.34 & $0-10$ \\
\hline Justifiability of Homosexuality & Never Justifiable $=1$ to Always $=10$ & 80,699 & 3.31 & 3.05 & $0-10$ \\
\hline Justifiability of Suicide & Never Justifiable $=1$ to Always $=10$ & 82,622 & 2.29 & 2.25 & $0-10$ \\
\hline Justifiability of Euthanasia & Never Justifiable $=1$ to Always $=10$ & 38,068 & 3.46 & 3.03 & $0-10$ \\
\hline Political Orientation & Right $=1$ to Left $=10$ & 66,270 & 5.29 & 2.31 & $0-10$ \\
\hline
\end{tabular}

Sources: Wave 6 (2010-2014) of the World Values Survey and additional country-level data from 2012 for GDP from United Nations and globalization from the KOF Swiss Economic Institute.

Missing data note: 105 (or .1\%) of cases imputed for age and 2,700 (or 3\%) cases imputed for the income scale. 
Table 2: Predominant Religious Affiliation, Religiousness, and Abortion Attitudes for All 56 Countries/Regions, Sorted by Gender Differences in Religiousness

\begin{tabular}{|c|c|c|c|c|c|c|}
\hline $\begin{array}{l}\text { Country/ } \\
\text { Region }\end{array}$ & $N$ & $\begin{array}{c}\text { Predominant } \\
\text { Affiliation }\end{array}$ & $\begin{array}{c}\text { Religiousness } \\
\text { (Standardized) }\end{array}$ & $\begin{array}{l}\text { Gender Gap } \\
(\text { Woman }=1)\end{array}$ & $\begin{array}{c}\text { Abortion } \\
(1-10)\end{array}$ & $\begin{array}{l}\text { Gender Gap } \\
(\text { Woman=1) }\end{array}$ \\
\hline Yemen & 1,000 & Muslim & .50 & -1.06 & 2.42 & 1.48 \\
\hline Iraq & 1,200 & Muslim & .63 & -.40 & 2.47 & .41 \\
\hline Algeria & 1,200 & Muslim & .61 & -.24 & 2.57 & .04 \\
\hline Jordan & 1,200 & Muslim & .79 & -.22 & 1.91 & .10 \\
\hline Palestine & 1,000 & Muslim & .67 & -.19 & 2.26 & .08 \\
\hline Kyrgyzstan & 1,500 & Muslim & .23 & -.12 & 2.37 & -.06 \\
\hline Pakistan & 1,200 & Muslim & .72 & -.10 & 1.52 & .15 \\
\hline Turkey & 1,605 & Muslim & .44 & -.10 & 2.24 & .06 \\
\hline Malaysia & 1,300 & Muslim ${ }^{a}$ & .53 & -.08 & 2.13 & -.17 \\
\hline Azerbaijan & 1,002 & Muslim & -.30 & -.04 & 2.93 & .67 \\
\hline Libya & 2,131 & Muslim & .75 & -.02 & 1.76 & .28 \\
\hline Uzbekistan & 1,500 & Muslim & -.31 & .00 & 2.54 & .40 \\
\hline Nigeria & 1,759 & Christian $^{\mathrm{a}}$ & .93 & .02 & 2.13 & .21 \\
\hline Morocco & 1,200 & Muslim & .81 & .05 & 1.76 & .30 \\
\hline Ghana & 1,552 & Christian $^{\mathrm{a}}$ & .94 & .06 & 1.71 & -.05 \\
\hline India & 5,656 & Hindu $^{\mathrm{a}}$ & .37 & .06 & 2.45 &.- .33 \\
\hline Lebanon & 1,200 & Muslim ${ }^{\mathrm{a}}$ & .29 & .06 & 3.13 & -.21 \\
\hline Thailand & 1,165 & Buddhist & -.28 & .06 & 1.94 & .03 \\
\hline Cyprus & 1,000 & $\mathrm{M} \& \mathrm{C}$ & .03 & .10 & 3.91 & -.11 \\
\hline Rwanda & 1,527 & Christian $^{\mathrm{a}}$ & .39 & .10 & 2.22 & -.05 \\
\hline Philippines & 1,200 & Christian & .78 & .11 & 3.13 & -.22 \\
\hline Tunisia & 1,205 & Muslim & .47 & .11 & 2.01 & .21 \\
\hline Hong Kong & 999 & Unaffiliated $^{\mathrm{a}}$ & -1.26 & .13 & 3.23 & -.46 \\
\hline Georgia & 1,202 & Christian & .48 & .14 & 1.83 & .33 \\
\hline Singapore & 1,972 & Pluralist & -.06 & .15 & 3.78 & -.20 \\
\hline China & 2,283 & Unaffiliated & -1.61 & .16 & 2.88 & -.13 \\
\hline Ecuador & 1,202 & Christian $^{\mathrm{a}}$ & .49 & .19 & 2.13 & -.02 \\
\hline Japan & 2,441 & Unaffiliated $^{\mathrm{a}}$ & -.87 & .21 & 4.76 & .03 \\
\hline Netherlands & 1,902 & Unaffiliated $^{\mathrm{a}}$ & -1.02 & .22 & 6.50 &.- .30 \\
\hline Taiwan & 1,238 & Pluralist & -.50 & .23 & 3.54 & -.15 \\
\hline Zimbabwe & 1,500 & Christian & .83 & .23 & 2.09 & -.09 \\
\hline Trinidad \& Tobago & 999 & Christian ${ }^{\mathrm{a}}$ & .66 & .24 & 2.17 & -.27 \\
\hline United States & 2,224 & Christian $^{\mathrm{a}}$ & .00 & .24 & 4.81 & .19 \\
\hline Colombia & 1,512 & Christian $^{\mathrm{a}}$ & .53 & .25 & 1.90 & -.13 \\
\hline Kazakhstan & 1,500 & Muslim ${ }^{\mathrm{a}}$ & -.40 & .25 & 3.48 & .45 \\
\hline Mexico & 2,000 & Christian & .41 & .25 & 2.88 & -.16 \\
\hline Peru & 1,210 & Christian & .32 & .25 & 2.43 & -.11 \\
\hline South Africa & 3,531 & Christian $^{\mathrm{a}}$ & .37 & .26 & 4.17 & .04 \\
\hline Slovenia & 1,065 & Christian $^{\mathrm{a}}$ & -.73 & .27 & 6.88 & .22 \\
\hline Germany & 2,046 & Christian $^{\mathrm{a}}$ & -1.02 & .29 & 4.77 & -.02 \\
\hline Australia & 1,474 & Christian $^{\mathrm{a}}$ & -.84 & .31 & 5.78 & .04 \\
\hline Armenia & 1,100 & Christian & .27 & .32 & 2.43 & .63 \\
\hline Brazil & 1,486 & Christian & .55 & .32 & 2.28 & -.28 \\
\hline Sweden & 1,206 & Christian ${ }^{\mathrm{a}}$ & -1.24 & .32 & 8.00 & .07 \\
\hline New Zealand & 835 & Christian ${ }^{\mathrm{a}}$ & -.78 & .35 & 5.22 & .06 \\
\hline Poland & 966 & Christian & .28 & .37 & 3.19 & -.27 \\
\hline Romania & 1,503 & Christian & .41 & .37 & 2.95 & -.25 \\
\hline Argentina & 1,030 & Christian $^{\mathrm{a}}$ & -.34 & .42 & 3.79 & -.59 \\
\hline Chile & 1,000 & Christian $^{\mathrm{a}}$ & -.17 & .44 & 3.23 & .17 \\
\hline Spain & 1,189 & Christian $^{\mathrm{a}}$ & -.96 & .44 & 5.50 & -.36 \\
\hline Estonia & 1,533 & Unaffiliated $^{\mathrm{a}}$ & -1.11 & .46 & 4.93 & .19 \\
\hline Uruguay & 1,000 & Unaffiliated $^{a}$ & -.65 & .46 & 3.87 & .01 \\
\hline South Korea & 1,200 & $C \& U$ & -.60 & .47 & 3.50 & -.01 \\
\hline Ukraine & 1,500 & Christian & -.15 & .49 & 3.67 & .06 \\
\hline Russia & 2,496 & Christian ${ }^{a}$ & -.62 & .57 & 4.34 & .25 \\
\hline Belarus & 1,535 & Christian $^{\mathrm{a}}$ & -.40 & .63 & 3.84 & .44 \\
\hline
\end{tabular}


Bolded gender differences significant at $p<.05$

${ }^{a}$ Predominant affiliation is less than $80 \%$ of the population (and more than $49 \%$ ). Most Christian countries where less than $80 \%$ of the population is Christian have substantial unaffiliated populations. Note: In pluralist contexts, no one group is over $40 \%$ of the population. In countries with two predominant religions, neither are $49 \%$ or more of the population and each at least $40 \%$ of the population. 
Table 3: Gender Differences in Standardized Religiousness in Multilevel Mixed-Effects Models

\begin{tabular}{|c|c|c|c|}
\hline & Model 1 & Model 2 & Model 3 \\
\hline Woman & $\begin{array}{l}.16^{* * *} \\
(.01)\end{array}$ & $\begin{array}{l}.11^{* * * *} \\
(.00)\end{array}$ & $\begin{array}{l}-.12^{* * * *} \\
(.01)\end{array}$ \\
\hline \multicolumn{4}{|c|}{ Religious Group (Muslim Reference) } \\
\hline Christian & & $\begin{array}{l}-.05^{* * * *} \\
(.01)\end{array}$ & $\begin{array}{l}-.23^{* * * *} \\
(.01)\end{array}$ \\
\hline Jewish & & $\begin{array}{l}-.51^{\text {**** }} \\
(.05)\end{array}$ & $\begin{array}{l}-.59^{* * *} \\
(.06)\end{array}$ \\
\hline Hindu & & $\begin{array}{l}-.05^{* * *} \\
(.02)\end{array}$ & $\begin{array}{l}-.14^{* * * *} \\
(.02)\end{array}$ \\
\hline Buddhist & & $\begin{array}{l}-.42^{\text {**** }} \\
(.02)\end{array}$ & $\begin{array}{l}-.56^{* * * *} \\
(.02)\end{array}$ \\
\hline Taoist & & $\begin{array}{l}-.40^{* * * *} \\
(.04)\end{array}$ & $\begin{array}{l}-.49^{* * * *} \\
(.05)\end{array}$ \\
\hline Unaffiliated & & $\begin{array}{c}-1.20^{* * *} \\
(.01)\end{array}$ & $\begin{array}{c}-1.35^{* * *} \\
(.01)\end{array}$ \\
\hline \multicolumn{4}{|c|}{ Interaction Terms (Muslim*Woman Reference) } \\
\hline Christian*Woman & & & $\begin{array}{l}.34^{* * * *} \\
(.01)\end{array}$ \\
\hline Jewish*Woman & & & $\begin{array}{l}.15 \\
(.09)\end{array}$ \\
\hline Hindu*Woman & & & $\begin{array}{l}.18^{* * * *} \\
(.02)\end{array}$ \\
\hline Buddhist*Woman & & & $\begin{array}{l}.28^{* * * *} \\
(.02)\end{array}$ \\
\hline Taoist*Woman & & & $\begin{array}{l}.18^{* * *} \\
(.06)\end{array}$ \\
\hline Unaffiliated*Woman & & & $\begin{array}{l}.30^{* * * *} \\
(.01)\end{array}$ \\
\hline \multicolumn{4}{|l|}{ Individual-Level Covariates } \\
\hline Age (In Decades) & $\begin{array}{l}.07^{* * * *} \\
(.00)\end{array}$ & $\begin{array}{l}.05^{* * * *} \\
(.00)\end{array}$ & $\begin{array}{l}.05^{* * * *} \\
(.00)\end{array}$ \\
\hline \multicolumn{4}{|c|}{ Education (Primary or Less Reference) } \\
\hline Incomplete Secondary & $\begin{array}{l}-.00 \\
(.01)\end{array}$ & $\begin{array}{c}.00 \\
(.01)\end{array}$ & $\begin{array}{l}-.01 \\
(.01)\end{array}$ \\
\hline Complete Secondary & $\begin{array}{l}-.02^{* * *} \\
(.01)\end{array}$ & $\begin{array}{l}-.01^{*} \\
(.01)\end{array}$ & $\begin{array}{l}-.02^{* * *} \\
(.01)\end{array}$ \\
\hline Some College & $\begin{array}{l}-.02^{*} \\
(.01)\end{array}$ & $\begin{array}{l}-.01 \\
(.01)\end{array}$ & $\begin{array}{l}-.02 \\
(.01)\end{array}$ \\
\hline College Degree or More & $\begin{array}{l}-.05^{* * * *} \\
(.01)\end{array}$ & $\begin{array}{l}-.03^{* * * *} \\
(.01)\end{array}$ & $\begin{array}{l}-.04^{* * * *} \\
(.01)\end{array}$ \\
\hline Income Scale (Self-Placement) & $\begin{array}{c}.00 \\
(.00)\end{array}$ & $\begin{array}{c}.00 \\
(.00)\end{array}$ & $\begin{array}{c}.00 \\
(.00)\end{array}$ \\
\hline \multicolumn{4}{|c|}{ Country-Level Covariates } \\
\hline Christian & $\begin{array}{l}-.15 \\
(.16)\end{array}$ & $\begin{array}{c}.03 \\
(.13)\end{array}$ & $\begin{array}{c}.03 \\
(.13)\end{array}$ \\
\hline Other or No Majority & $\begin{array}{l}-.68^{* * *} \\
(.20)\end{array}$ & $\begin{array}{l}-.20 \\
(.17)\end{array}$ & $\begin{array}{l}-.20 \\
(.17)\end{array}$ \\
\hline Logged Per Capita PPP GDP & $\begin{array}{l}-.31^{* * * *} \\
(.09)\end{array}$ & $\begin{array}{l}-.20^{* * *} \\
(.08)\end{array}$ & $\begin{array}{l}-.20^{* *} \\
(.08)\end{array}$ \\
\hline Globalization Index & $\begin{array}{l}-.01 \\
(.01)\end{array}$ & $\begin{array}{l}-.01 \\
(.01)\end{array}$ & $\begin{array}{l}-.01 \\
(.01)\end{array}$ \\
\hline Constant & .24 & .49 & .61 \\
\hline$N$ & 85,181 & 85,181 & 85,181 \\
\hline
\end{tabular}

Standard errors in parentheses; ${ }^{*} p<0.05,{ }^{* *} p<0.01,{ }^{* * *} p<0.001$

Sources: World Values Survey, Wave 6 (2010-2014), United Nations (2012), and KOF (2012).

Note: Models also include categories (not shown) for other/missing affiliation and missing education. 
Table 4: Relationship between Standardized Religiousness and Traditional Moral Values across Groups

\begin{tabular}{|c|c|c|c|c|c|c|}
\hline & $\begin{array}{c}\text { Abortion } \\
(\mathbf{1 - 1 0})\end{array}$ & $\begin{array}{c}\text { Premarital } \\
\text { Sex } \\
(1-10) \\
\end{array}$ & $\begin{array}{c}\text { Homosex- } \\
\text { uality } \\
(1-10) \\
\end{array}$ & $\begin{array}{c}\text { Suicide } \\
(1-10) \\
\end{array}$ & $\begin{array}{c}\text { Euthanasia } \\
(1-10)\end{array}$ & $\begin{array}{c}\text { Political } \\
\text { Orientation } \\
(1-10) \\
\end{array}$ \\
\hline$N$ & 82,180 & $75,587^{\mathrm{a}}$ & 80,699 & 82,622 & $38,068^{\mathrm{b}}$ & $66,270^{c}$ \\
\hline \multirow[t]{2}{*}{ Full Sample } & $-.73^{* * *}$ & $-.69^{* * *}$ & $-.54^{* * *}$ & $-.39^{* * *}$ & $-.62^{* * *}$ & $-.35^{* * *}$ \\
\hline & $(.01)$ & $(.01)$ & $(.01)$ & $(.01)$ & $(.02)$ & $(.01)$ \\
\hline \multirow[t]{2}{*}{ Muslims } & $-.56^{* * *}$ & $-.44^{* * *}$ & $-.29^{* * *}$ & $-.33^{* * *}$ & $-.41^{* * *}$ & $-.49^{* * *}$ \\
\hline & $(.03)$ & $(.03)$ & $(.02)$ & $(.02)$ & $(.04)$ & $(.03)$ \\
\hline \multirow[t]{2}{*}{ Christians } & $-.90^{* * *}$ & $-.88^{* * *}$ & $-.59^{* * *}$ & $-.37^{* * * *}$ & $-.80^{* * *}$ & $-.30^{* * *}$ \\
\hline & $(.02)$ & $(.02)$ & $(.02)$ & $(.02)$ & $(.04)$ & $(.02)$ \\
\hline \multirow[t]{2}{*}{ Jews } & $-.48^{*}$ & $-.67^{* *}$ & -.37 & .04 & .19 & $-.68^{* *}$ \\
\hline & $(.23)$ & $(.26)$ & $(.25)$ & $(.24)$ & $(.62)$ & $(.22)$ \\
\hline \multirow[t]{2}{*}{ Hindus } & $-.86^{* * *}$ & $-.91^{* * *}$ & $-.82^{* * *}$ & $-.82^{* * * *}$ & $-.31^{*}$ & $-.43^{* * *}$ \\
\hline & $(.06)$ & $(.06)$ & $(.06)$ & $(.06)$ & (.14) & $(.06)$ \\
\hline \multirow[t]{2}{*}{ Buddhists } & $-.24^{* * *}$ & $-.38^{* * * *}$ & $-.24^{* * *}$ & $-.24^{* * *}$ & .01 & $-.13^{*}$ \\
\hline & $(.06)$ & $(.07)$ & $(.07)$ & $(.05)$ & (.13) & $(.07)$ \\
\hline \multirow[t]{2}{*}{ Taoists } & .08 & .01 & .03 & -.14 & -.52 & -.02 \\
\hline & $(.18)$ & $(.18)$ & $(.19)$ & $(.16)$ & $(.29)$ & $(.20)$ \\
\hline \multirow[t]{2}{*}{ Unaffiliated } & $-.50^{* * *}$ & $-.42^{* * *}$ & $-.34^{* * *}$ & $-.32^{* * * *}$ & $-.34^{* * *}$ & $-.33^{* * *}$ \\
\hline & $(.03)$ & $(.03)$ & $(.03)$ & $(.03)$ & $(.05)$ & $(.03)$ \\
\hline \multirow[t]{2}{*}{ Catholics } & $-.98^{* * * *}$ & $-.80^{* * * *}$ & $-.61^{* * *}$ & $-.44^{* * * *}$ & $-.68^{* * * *}$ & $-.38^{* * * *}$ \\
\hline & $(.03)$ & $(.04)$ & $(.04)$ & $(.03)$ & $(.06)$ & $(.03)$ \\
\hline \multirow[t]{2}{*}{ Orthodox Christians } & $-.72^{* * *}$ & $-.64^{* * *}$ & $-.24^{* * *}$ & $-.16^{* * *}$ & $-.66^{* * * *}$ & $-.17^{* * * *}$ \\
\hline & $(.04)$ & $(.05)$ & $(.04)$ & $(.03)$ & $(.12)$ & $(.04)$ \\
\hline \multirow[t]{2}{*}{ Protestants } & $-.89^{* * *}$ & $-1.05^{* * *}$ & $-.77^{* * *}$ & $-.45^{* * *}$ & $-.87^{* * *}$ & $-.28^{* * *}$ \\
\hline & $(.04)$ & $(.04)$ & $(.04)$ & $(.03)$ & $(.06)$ & $(.04)$ \\
\hline \multirow[t]{2}{*}{ Majority Muslims } & $-.47^{* * * *}$ & $-.30^{* * * *}$ & $-.20^{* * *}$ & $-.27^{* * * *}$ & $-.41^{* * * *}$ & $-.51^{* * * *}$ \\
\hline & $(.03)$ & $(.03)$ & $(.02)$ & $(.02)$ & $(.04)$ & $(.04)$ \\
\hline \multirow[t]{2}{*}{ Minority Muslims } & $-1.02^{* * *}$ & $-.93^{* * *}$ & $-.80^{* * *}$ & $-.67^{* * *}$ & -.28 & $-.40^{* * *}$ \\
\hline & $(.08)$ & $(.09)$ & $(.07)$ & $(.07)$ & $(.21)$ & $(.09)$ \\
\hline \multirow[t]{2}{*}{ Majority Christians } & $-.89^{* * * *}$ & $-.87^{* * *}$ & $-.57^{* * * *}$ & $-.34^{* * * *}$ & $-.72^{* * * *}$ & $-.31^{* * * *}$ \\
\hline & $(.02)$ & $(.03)$ & $(.02)$ & $(.02)$ & $(.04)$ & $(.02)$ \\
\hline \multirow[t]{2}{*}{ Minority Christians } & $-.93^{* * *}$ & $-.95^{* * *}$ & $-.70^{* * * *}$ & $-.54^{* * * *}$ & $-1.18^{* * *}$ & $-.21^{* * *}$ \\
\hline & $(.06)$ & $(.06)$ & $(.06)$ & $(.05)$ & $(.10)$ & $(.05)$ \\
\hline Christians in Sub- & $-.61^{* * *}$ & $-.61^{* * *}$ & $-.49^{* * *}$ & $-.60^{* * *}$ & $-.42^{* * *}$ & $-.17^{*}$ \\
\hline Saharan Africa & $(.07)$ & $(.08)$ & $(.06)$ & $(.07)$ & $(.09)$ & $(.08)$ \\
\hline Unaffiliated in & $-.57^{* * * *}$ & $-.52^{* * *}$ & $-.46^{* * *}$ & $-.39^{* * * *}$ & $-.38^{* * *}$ & $-.38^{* * * *}$ \\
\hline Christian Contexts & $(.04)$ & $(.04)$ & $(.04)$ & $(.04)$ & $(.07)$ & $(.04)$ \\
\hline Unaffiliated in non- & $-.39^{* * *}$ & $-.27^{* * * *}$ & $-.17^{* * * *}$ & $-.22^{* * * *}$ & $-.29^{* * * *}$ & $-.24^{* * * *}$ \\
\hline Christian Contexts & $(.05)$ & $(.05)$ & $(.05)$ & $(.04)$ & $(.08)$ & $(.04)$ \\
\hline
\end{tabular}

Standard errors in parentheses; ${ }^{*} p<0.05,{ }^{* * *} p<0.01,{ }^{* * * *} p<0.001$

Sources: World Values Survey, Wave 6 (2010-2014), United Nations (2012), and KOF (2012).

${ }^{a}$ The premarital sex item was not fielded in Algeria, Palestine, Iraq, Lebanon, Tunisia, or Yemen.

${ }^{\mathrm{b}}$ Euthanasia was fielded in Algeria, Azerbaijan, Armenia, Brazil, China, Taiwan, Colombia, Ecuador, Georgia, Palestine, Hong Kong, among a subset in India, Iraq, Lebanon, Libya, Mexico, Netherlands, New Zealand, Pakistan, Peru, Philippines, Rwanda, Slovenia, South Africa, Sweden, Thailand, Tunisia, Uruguay, and Yemen.

${ }^{\mathrm{c}}$ Political orientation was not fielded in China, Jordan, and Singapore (and only available for a subset of the population in Algeria, Armenia, Russia, Trinidad and Tobago, Tunisia, Uzbekistan, and Yemen).

Note: Multilevel mixed-effects models include gender, age, education, income, predominant religion, GDP, and globalization. 
Table 5: Gender Differences in Abortion Attitudes before and after Accounting for Religiousness in Multilevel Mixed-Effects Models

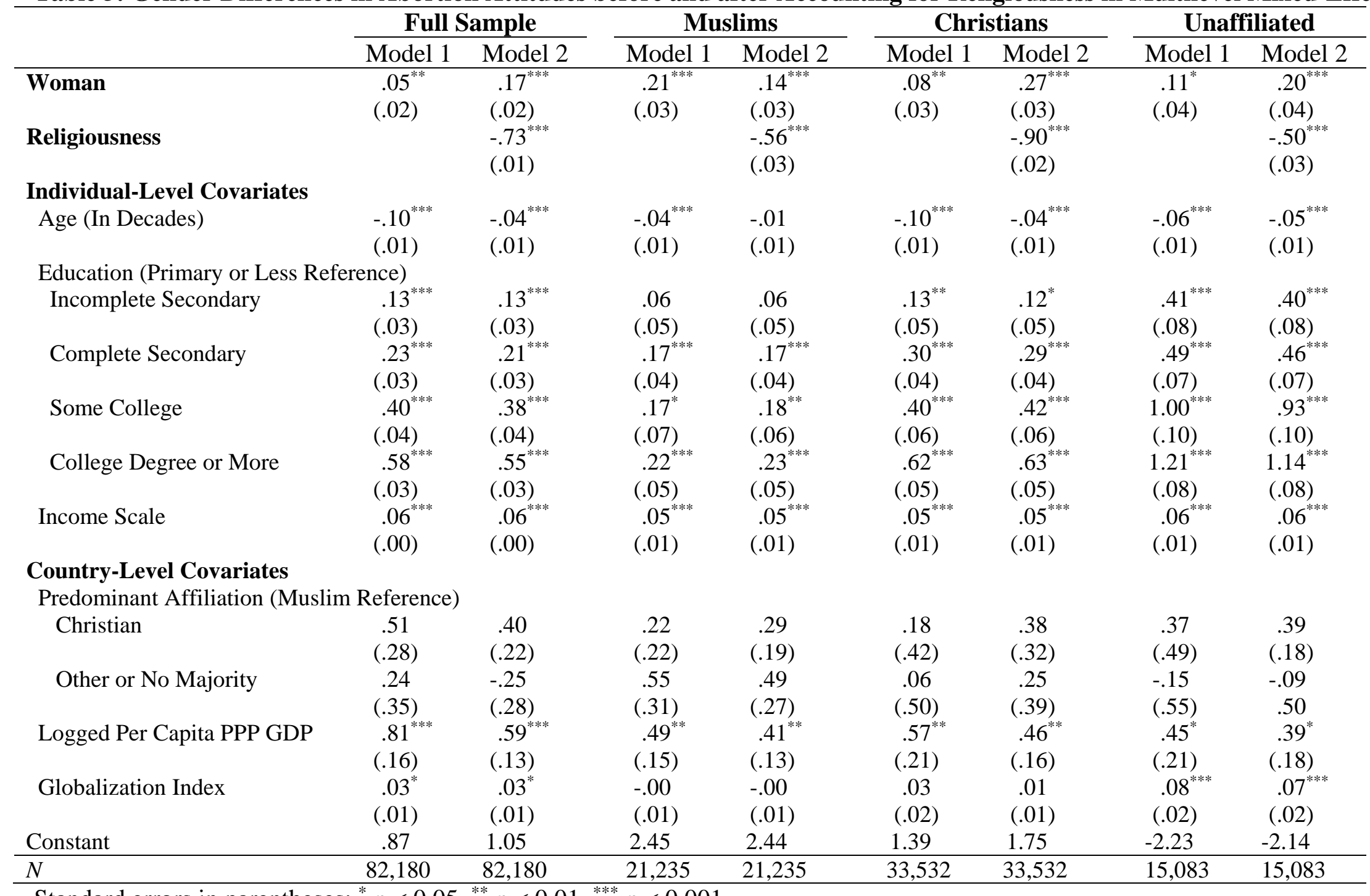

Standard errors in parentheses; ${ }^{*} p<0.05,{ }^{* *} p<0.01,{ }^{* * *} p<0.001$

Sources: World Values Survey, Wave 6 (2010-2014) and KOF (2012).

Note: Models also include categories (not shown) for other/missing affiliation and missing education. 
Table 6: Gender Differences in Sexuality Attitudes before (Model 1) and after (Model 2) Accounting for Religiousness

\begin{tabular}{|c|c|c|c|c|c|c|}
\hline & \multicolumn{2}{|c|}{ Abortion } & \multicolumn{2}{|c|}{ Premarital Sex } & \multicolumn{2}{|c|}{ Homosexuality } \\
\hline & Model 1 & Model 2 & Model 1 & Model 2 & Model 1 & Model 2 \\
\hline$N$ & 82,180 & 82,180 & 75,587 & 75,587 & 80,699 & 80,699 \\
\hline \multirow[t]{2}{*}{ Full Sample } & $.05^{* *}$ & $.17^{* * *}$ & $-.24^{* * *}$ & $-.10^{* * * *}$ & $.31^{* * * *}$ & $.39^{* * *}$ \\
\hline & $(.02)$ & $(.02)$ & $(.02)$ & $(.02)$ & $(.02)$ & $(.02)$ \\
\hline \multirow[t]{2}{*}{ Muslims } & $.21^{* * * *}$ & $.14^{* * *}$ & $-.09^{* *}$ & $-.11^{* * *}$ & $.13^{* * *}$ & $.09^{* * *}$ \\
\hline & $(.03)$ & $(.03)$ & $(.03)$ & $(.03)$ & $(.02)$ & $(.02)$ \\
\hline \multirow[t]{2}{*}{ Christians } & $.08^{* *}$ & $.27^{* * * *}$ & $-.27^{* * * *}$ & $-.08^{* *}$ & $.38^{* * * *}$ & $.51^{* * *}$ \\
\hline & $(.03)$ & $(.03)$ & $(.03)$ & $(.03)$ & $(.03)$ & $(.03)$ \\
\hline \multirow[t]{2}{*}{ Jews } & .52 & .51 & .42 & .43 & .01 & .03 \\
\hline & $(.38)$ & $(.38)$ & $(.40)$ & $(.40)$ & $(.38)$ & (.38) \\
\hline \multirow[t]{2}{*}{ Hindus } & $-.31^{* * * *}$ & $-.27^{* * *}$ & $-.35^{* * *}$ & $-.31^{* * * *}$ & -.07 & -.04 \\
\hline & $(.07)$ & $(.07)$ & $(.07)$ & $(.07)$ & $(.07)$ & $(.07)$ \\
\hline \multirow[t]{2}{*}{ Buddhists } & .01 & .04 & -.13 & -.08 & $.35^{* * *}$ & $.38^{* * * *}$ \\
\hline & $(.07)$ & $(.07)$ & $(.08)$ & $(.08)$ & $(.08)$ & $(.08)$ \\
\hline \multirow[t]{2}{*}{ Taoists } & $-.43^{*}$ & $-.44^{*}$ & $-.60^{* * *}$ & $-.60^{* * * *}$ & $.63^{* *}$ & $.62^{* *}$ \\
\hline & $(.22)$ & $(.22)$ & $(.22)$ & $(.22)$ & $(.23)$ & $(.23)$ \\
\hline \multirow[t]{2}{*}{ Unaffiliated } & $.11^{*}$ & $.20^{* * *}$ & $-.16^{* * * *}$ & -.08 & $.63^{* * *}$ & $.70^{* * *}$ \\
\hline & (.04) & $(.04)$ & $(.04)$ & $(.04)$ & $(.04)$ & $(.04)$ \\
\hline \multirow[t]{2}{*}{ Catholics } & .02 & $.21^{* * * *}$ & $-.27^{* * * *}$ & $-.11^{*}$ & $.46^{* * * *}$ & $.58^{* * * *}$ \\
\hline & $(.04)$ & $(.04)$ & $(.05)$ & $(.05)$ & $(.05)$ & $(.05)$ \\
\hline \multirow[t]{2}{*}{ Orthodox Christians } & $.16^{* * *}$ & $.40^{* * * *}$ & $-.34^{* * * *}$ & $-.12^{* * * *}$ & $.27^{* * *}$ & $.35^{* * *}$ \\
\hline & $(.06)$ & $(.06)$ & $(.07)$ & $(.07)$ & $(.05)$ & $(.05)$ \\
\hline \multirow[t]{2}{*}{ Protestants } & .08 & $.23^{* * *}$ & $-.21^{* * *}$ & -.03 & $.35^{* * *}$ & $.48^{* * *}$ \\
\hline & $(.05)$ & $(.04)$ & $(.05)$ & $(.05)$ & $(.05)$ & $(.05)$ \\
\hline \multirow[t]{2}{*}{ Majority Muslims } & $.25^{* * * *}$ & $.19^{* * * *}$ & $-.08^{*}$ & $-.10^{* *}$ & $.12^{* * *}$ & $.10^{* * *}$ \\
\hline & $(.03)$ & $(.03)$ & (.03) & $(.03)$ & $(.02)$ & $(.02)$ \\
\hline \multirow[t]{2}{*}{ Minority Muslims } & -.08 & -.06 & -.14 & -.12 & .14 & $.16^{* * *}$ \\
\hline & $(.09)$ & $(.09)$ & $(.10)$ & $(.10)$ & $(.09)$ & $(.08)$ \\
\hline \multirow[t]{2}{*}{ Majority Christians } & $.09^{* *}$ & $.28^{* * *}$ & $-.29^{* * *}$ & $-.10^{* *}$ & $.38^{* * *}$ & $.51^{* * *}$ \\
\hline & $(.03)$ & $(.03)$ & $(.03)$ & $(.03)$ & $(.03)$ & $(.03)$ \\
\hline \multirow[t]{2}{*}{ Minority Christians } & .00 & $.22^{* *}$ & $-.18^{*}$ & .06 & $.34^{* * *}$ & $.51^{* * *}$ \\
\hline & $(.08)$ & $(.08)$ & (.09) & (.09) & $(.08)$ & $(.08)$ \\
\hline Christians in Sub- & .04 & .10 & $-.27^{* * *}$ & $-.21^{* * * *}$ & .04 & .09 \\
\hline Saharan Africa & $(.05)$ & $(.05)$ & $(.06)$ & $(.06)$ & $(.05)$ & $(.05)$ \\
\hline Unaffiliated in & $.18^{* *}$ & $.30^{* * * *}$ & -.11 & .01 & $.77^{* * * *}$ & $.87^{* * * *}$ \\
\hline Christian Contexts & $(.06)$ & $(.06)$ & $(.06)$ & $(.06)$ & $(.06)$ & $(.07)$ \\
\hline Unaffiliated in non- & .04 & .10 & $-.20^{* * * *}$ & $-.16^{* * * *}$ & $.49^{* * * *}$ & $.52^{* * * *}$ \\
\hline Christian Contexts & $(.06)$ & $(.06)$ & $(.06)$ & $(.06)$ & $(.06)$ & $(.06)$ \\
\hline
\end{tabular}

Standard errors in parentheses; ${ }^{*} p<0.05,{ }^{* *} p<0.01,{ }^{* * * *} p<0.001$

Sources: World Values Survey, Wave 6 (2010-2014), United Nations (2012), and KOF (2012).

Note: All models include gender, age, education, income, predominant religion, GDP, and globalization.

The premarital sex item was not fielded in Algeria, Palestine, Iraq, Lebanon, Tunisia, or Yemen. Model 1 does not include religiousness and Model 2 does include religiousness. 
Gender, Religion, and Politics 46

Table 7: Gender Differences in End-of-Life Attitudes and Political Orientation before (Model 1) and after (Model 2) Accounting for Religiousness

\begin{tabular}{|c|c|c|c|c|c|c|}
\hline & \multicolumn{2}{|c|}{ Suicide } & \multicolumn{2}{|c|}{ Euthanasia } & \multicolumn{2}{|c|}{ Political Orientation } \\
\hline & Model 1 & Model 2 & Model 1 & Model 2 & Model 1 & Model 2 \\
\hline$N$ & 82,622 & 82,622 & $38,068^{a}$ & $38,068^{\mathrm{a}}$ & $66,270^{\mathrm{b}}$ & $66,270^{\mathrm{b}}$ \\
\hline \multirow{2}{*}{ Full Sample } & $-.07^{* * *}$ & -.00 & .01 & $.08^{* *}$ & $.04^{*}$ & $.10^{* * *}$ \\
\hline & $(.01)$ & $(.01)$ & $(.03)$ & $(.03)$ & $(.02)$ & $(.02)$ \\
\hline \multirow[t]{2}{*}{ Muslims } & .01 & -.03 & $.14^{* * *}$ & $.08^{*}$ & $.09^{*}$ & -.04 \\
\hline & (.02) & $(.02)$ & $(.04)$ & $(.04)$ & $(.04)$ & $(.04)$ \\
\hline \multirow[t]{2}{*}{ Christians } & -.03 & $.05^{*}$ & -.01 & $.12^{* *}$ & .03 & $.09^{* *}$ \\
\hline & $(.02)$ & $(.02)$ & (.04) & $(.04)$ & $(.03)$ & $(.03)$ \\
\hline \multirow[t]{2}{*}{ Jews } & .37 & .38 & -.37 & -.36 & .60 & .57 \\
\hline & $(.39)$ & $(.39)$ & (.91) & $(.91)$ & $(.37)$ & $(.36)$ \\
\hline \multirow[t]{2}{*}{ Hindus } & $-.33^{* * * *}$ & $-.28^{* * * *}$ & -.07 & -.07 & $.23^{* *}$ & $.25^{* *}$ \\
\hline & $(.07)$ & $(.07)$ & (.16) & (.16) & $(.07)$ & $(.07)$ \\
\hline \multirow[t]{2}{*}{ Buddhists } & .05 & .08 & $.32^{*}$ & $.32^{*}$ & .02 & .04 \\
\hline & $(.06)$ & $(.06)$ & (.14) & (.14) & $(.08)$ & $(.08)$ \\
\hline \multirow[t]{2}{*}{ Taoists } & $-.59^{* *}$ & $-.58^{* *}$ & -.16 & -.12 & .22 & .22 \\
\hline & $(.20)$ & $(.20)$ & $(.36)$ & $(.36)$ & $(.25)$ & $(.25)$ \\
\hline \multirow[t]{2}{*}{ Unaffiliated } & -.08 & -.02 & -.02 & .02 & .03 & $.10^{* * *}$ \\
\hline & (.04) & $(.04)$ & $(.07)$ & (.07) & (.04) & $(.04)$ \\
\hline \multirow[t]{2}{*}{ Catholics } & .04 & $.12^{* * *}$ & .02 & $.13^{*}$ & .02 & $.09^{*}$ \\
\hline & $(.04)$ & $(.04)$ & $(.06)$ & $(.06)$ & $(.04)$ & (.04) \\
\hline \multirow[t]{2}{*}{ Orthodox Christians } & $-.10^{* * *}$ & .04 & -.04 & .07 & -.03 & .03 \\
\hline & $(.04)$ & $(.04)$ & $(.11)$ & $(.11)$ & $(.05)$ & $(.06)$ \\
\hline \multirow[t]{2}{*}{ Protestants } & -.08 & -.00 & -.03 & .12 & .07 & $.12^{*}$ \\
\hline & $(.04)$ & $(.04)$ & $(.07)$ & $(.07)$ & $(.05)$ & $(.05)$ \\
\hline \multirow[t]{2}{*}{ Majority Muslims } & .01 & -.02 & $.19^{* * *}$ & $.13^{* *}$ & .07 & .01 \\
\hline & $(.02)$ & $(.02)$ & $(.04)$ & $(.04)$ & $(.04)$ & $(.04)$ \\
\hline \multirow[t]{2}{*}{ Minority Muslims } & -.00 & .02 & $-.65^{* *}$ & $-.63^{* *}$ & .14 & .14 \\
\hline & $(.09)$ & $(.08)$ & $(.23)$ & $(.23)$ & $(.10)$ & $(.10)$ \\
\hline \multirow[t]{2}{*}{ Majority Christians } & -.02 & $.06^{*}$ & -.03 & $.09^{*}$ & .04 & $.10^{* *}$ \\
\hline & $(.02)$ & $(.02)$ & $(.05)$ & $(.05)$ & $(.03)$ & $(.03)$ \\
\hline \multirow[t]{2}{*}{ Minority Christians } & $-.14^{*}$ & -.02 & .12 & $.32^{*}$ & -.01 & .04 \\
\hline & (.06) & $(.06)$ & (.14) & (.14) & $(.08)$ & $(.08)$ \\
\hline Christians in Sub- & -.04 & .02 & .04 & .08 & $.11^{\mathrm{c}}$ & $-.13^{* c}$ \\
\hline Saharan Africa & $(.05)$ & $(.05)$ & $(.08)$ & $(.09)$ & $(.06)$ & $(.06)$ \\
\hline Unaffiliated in & -.01 & .08 & -.03 & .04 & $.13^{*}$ & $.21^{* * * *}$ \\
\hline Christian Contexts & $(.06)$ & $(.06)$ & (.10) & $(.10)$ & $(.05)$ & $(.05)$ \\
\hline Unaffiliated in non- & $-.14^{*}$ & -.10 & -.02 & .01 & $-.11^{*}$ & -.06 \\
\hline Christian Contexts & $(.05)$ & $(.05)$ & $(.09)$ & $(.09)$ & $(.06)$ & $(.06)$ \\
\hline
\end{tabular}

Standard errors in parentheses; ${ }^{*} p<0.05,{ }^{* *} p<0.01,{ }^{* * *} p<0.001$

Sources: World Values Survey, Wave 6 (2010-2014), United Nations (2012), and KOF (2012).

${ }^{a}$ Euthanasia was fielded in Algeria, Azerbaijan, Armenia, Brazil, China, Taiwan, Colombia, Ecuador, Georgia,

Palestine, Hong Kong, among a subset in India, Iraq, Lebanon, Libya, Mexico, Netherlands, New Zealand,

Pakistan, Peru, Philippines, Rwanda, Slovenia, South Africa, Sweden, Thailand, Tunisia, Uruguay, and Yemen.

${ }^{\mathrm{b}}$ Political orientation was not fielded in China, Jordan, and Singapore (and only available for a subset of the population in Algeria, Armenia, Russia, Trinidad and Tobago, Tunisia, Uzbekistan, and Yemen).

${ }^{\mathrm{c}}$ Single imputation used for this model because multiple imputation model did not converge.

Note: Models include gender, age, education, income, predominant religion, GDP, and globalization. 
Figure 1: Gender Differences in Standardized Religiousness across Groups

$$
\begin{aligned}
& \text { Orthodox Christians }(\mathrm{N}=8,079) \\
& \text { Christians in Western Contexts }(\mathrm{N}=7,654) \\
& \text { Christians in non-Muslim/Christian Contexts }(\mathrm{N}=3,217) \\
& \text { Unaffiliated in Christian Contexts }(\mathrm{N}=7,775) \\
& \text { All Christians }(\mathrm{N}=34,395) \\
& \text { Unaffiliated in Muslim Contexts (N=397) } \\
& \text { Christians in Christian Contexts }(\mathrm{N}=30,023) \\
& \text { Christians in Non-Western Contexts }(\mathrm{N}=26,741) \\
& \text { Catholics }(\mathrm{N}=14,850) \\
& \text { Christians in Muslims Contexts }(\mathrm{N}=1,155) \\
& \text { All Unaffiliated }(\mathrm{N}=16,031) \\
& \text { Protestants }(\mathrm{N}=11,466) \\
& \text { Full Sample }(\mathrm{N}=85,181) \\
& \text { Unaffiliated in non-Muslim/Christian Contexts }(\mathrm{N}=7,859) \\
& \text { All Buddhists }(\mathrm{N}=3,844) \\
& \text { Christians in Sub-Saharan Africa }(\mathrm{N}=6,667) \\
& \text { All Taoists }(\mathrm{N}=406) \\
& \text { All Jews }(\mathrm{N}=189) \\
& \text { All Hindus }(\mathrm{N}=5,003) \\
& \text { Muslims in Christian Contexts }(\mathrm{N}=1543) \\
& \text { Muslims in non-Muslim/Christian Contexts }(\mathrm{N}=1,505) \\
& \text { All Muslims }(\mathrm{N}=21,761) \\
& \text { Muslims in Muslim Contexts }(\mathrm{N}=18,713)
\end{aligned}
$$

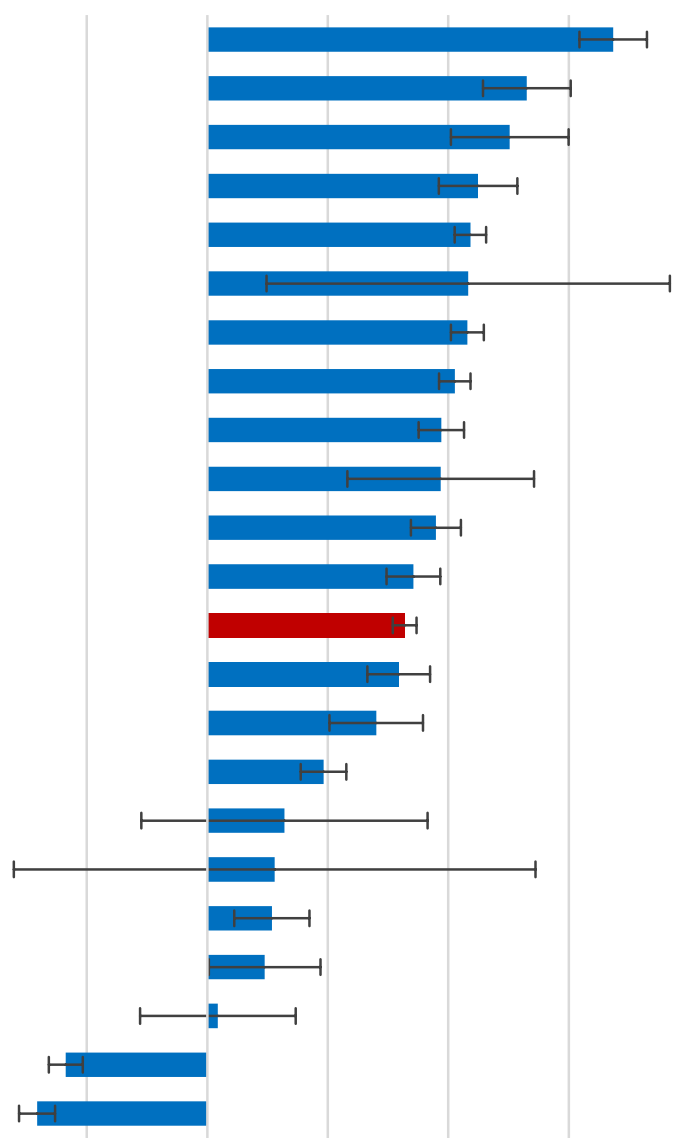

$$
-0.2
$$

$-0.1 \quad 0$

0.1

0.2

0.3

0.4

Men More Religious | Women More Religious

Error bars indicate $95 \%$ confidence intervals

Estimates based on multilevel models that include gender, age, education, income, predominant religion, GDP, and globalization.

Note: Western contexts include Australia, Estonia, Germany, Netherlands, New Zealand, Poland, Slovenia, Spain, Sweden, and United States (non-Western contexts include all other countries/regions in the sample). Sub-Saharan African contexts include Ghana, Nigeria, Rwanda, South Africa, and Zimbabwe. 
Figure A1: Gender Gaps in Religiousness by Proportion Muslim and Christian

Panel A: Gender Gaps in Religiousness by Proportion Muslim
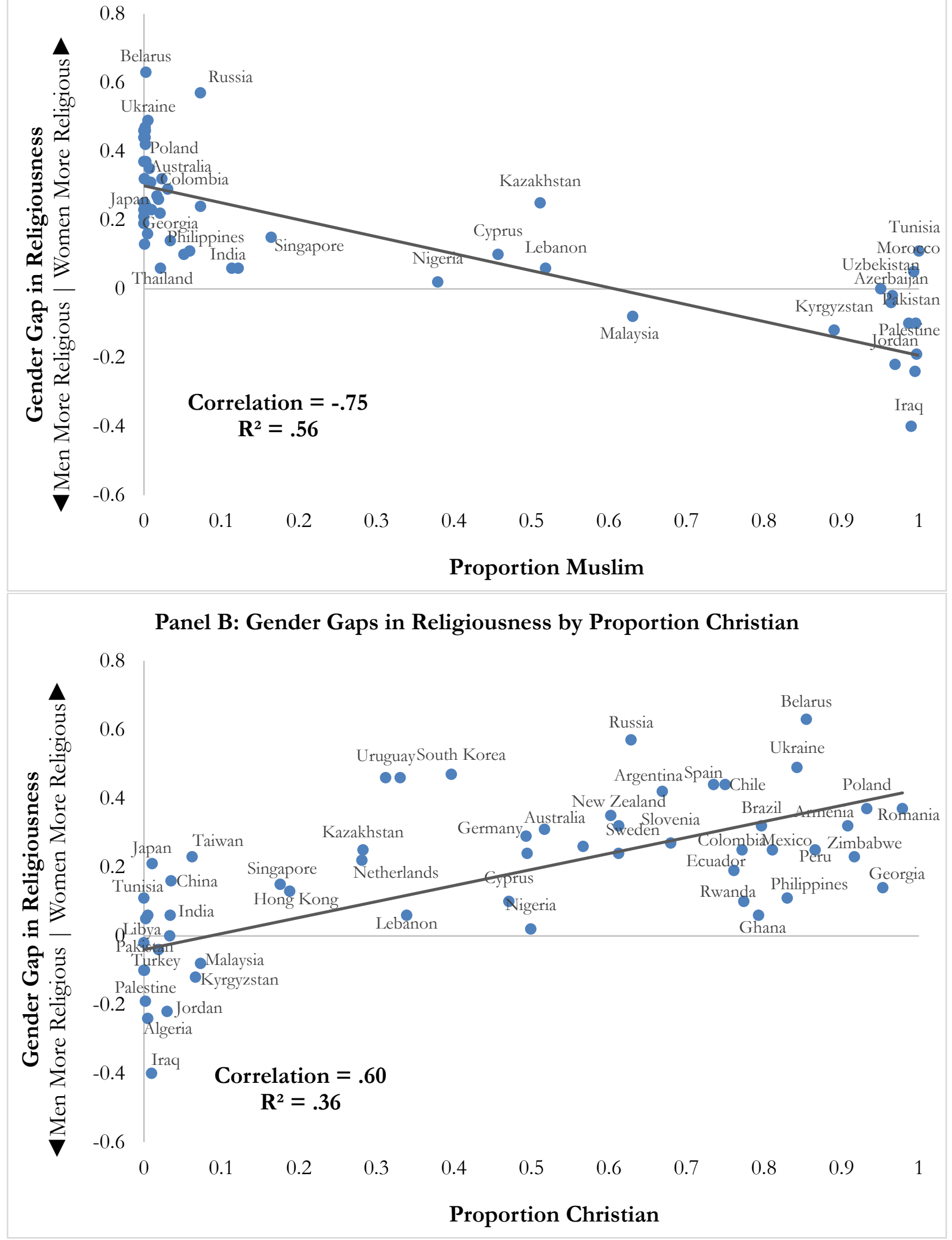
Gender, Religion, and Politics 49

Source: World Values Survey

Note: Scale set from -.6 to .8 for better readability and thus Yemen is not shown. 